Portland State University

PDXScholar

$9-21-1977$

\title{
Bird Use of Revetted Riverbanks in the Willamette Valley
}

Clifford Brian Perry

Portland State University

Follow this and additional works at: https://pdxscholar.library.pdx.edu/open_access_etds

Part of the Agriculture Commons, and the Ornithology Commons Let us know how access to this document benefits you.

\section{Recommended Citation}

Perry, Clifford Brian, "Bird Use of Revetted Riverbanks in the Willamette Valley" (1977). Dissertations and Theses. Paper 2858.

https://doi.org/10.15760/etd.2852

This Thesis is brought to you for free and open access. It has been accepted for inclusion in Dissertations and Theses by an authorized administrator of PDXScholar. Please contact us if we can make this document more accessible: pdxscholar@pdx.edu. 
AN ABSTRACT OF THE THESIS OF Clifford Brian Perry for the Master of Science in Biology presented September 21, 1977.

Title: Bird Use of Revetted Riverbanks in the Willamette Valley. APPROVED BY MEMBERS OF THE THESIS COMMITTEE:

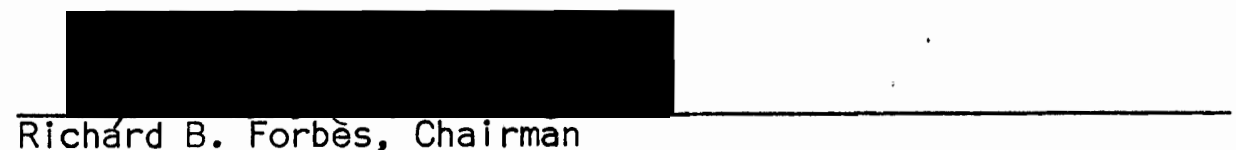
Richárd B. Forbès, Chairman

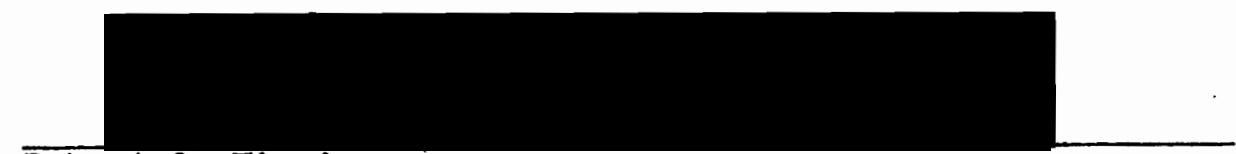
Robert 0. Tinnin
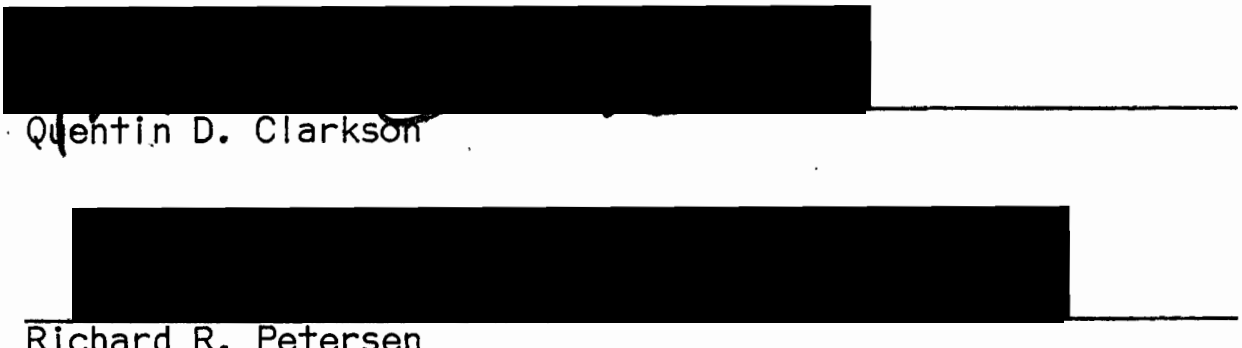

Over 115 miles of rock revetments that serve to protect river banks have been constructed in the Willamette Basin. In this study the spring and summer bird use of Williamette Basin revetments is examined. Revetments that had not been recently cleared of most woody vegetation and blackberries were found to have significantly greater total and breeding bird use than cleared revetments. Possible factors affecting bird use, such as vegetation on revetments and vegetation adjacent to revetments are examined using linear regression analysis. The results 
of this study are compared with results of previous work in riparian forests along the Columbia River. It is concluded that revetments represent significant avian habitat, especially for "edge species," and that present maintenance practices involving removal of vegetation adversely affect bird use. 
BIRD USE OF REVETTED RIVERBANKS IN THE WILLAMETTE VALLEY

$$
\text { by }
$$

CLIFFORD BRIAN PERRY

\begin{abstract}
A thesis submitted in partial fulfillment of the requirements for the degree of
\end{abstract}

\author{
MASTER OF SCIENCE \\ in \\ BIOLOGY
}

Portland State University

1978 
TO THE OFFICE OF GRADUATE STUDIES AND RESEARCH:

The members of the Committee approved the thesis of Clifford Brian Perry presented September 21, 1977.

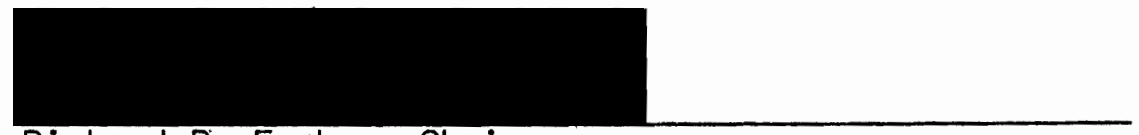

Richard B. Forbes, Chairman
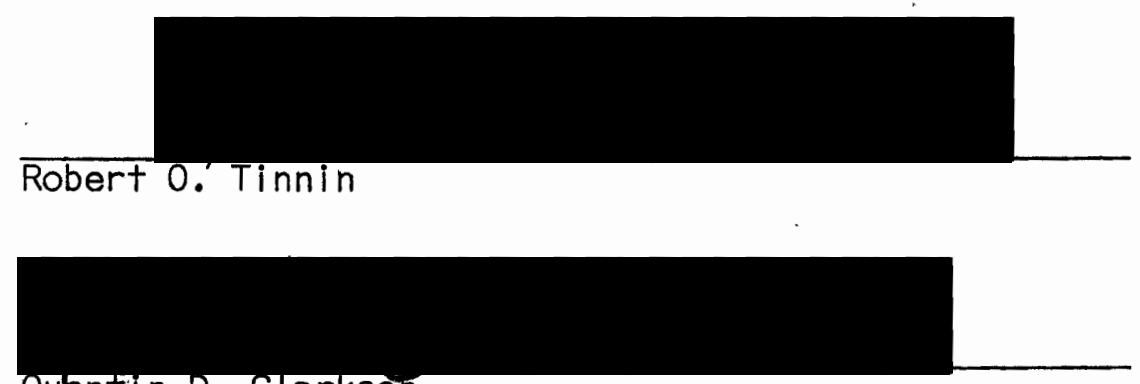

Quentin D. Clarkson

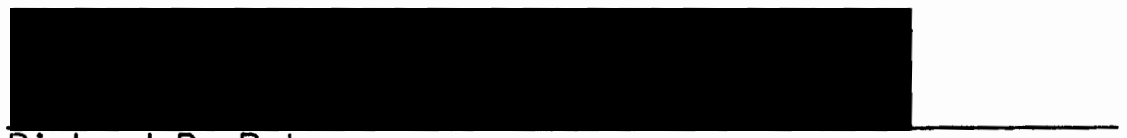

Richard, R. Petersen

APPROVED:

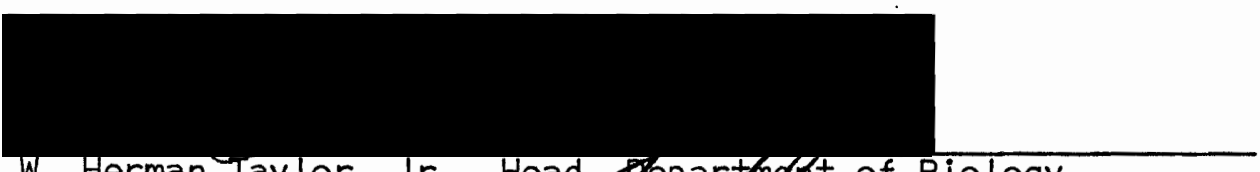

W. Herman laylor, Jr., Head Eepartinett of Biology

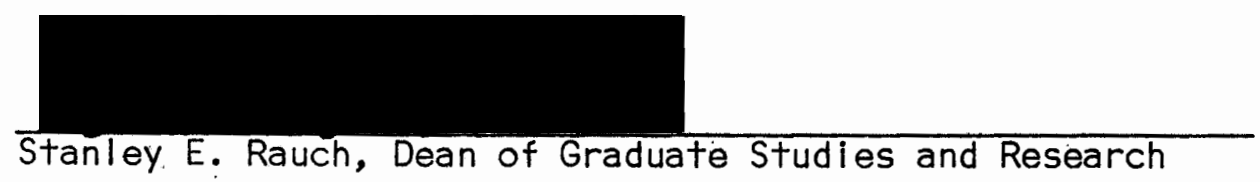




\section{ACKNOWLEDGEMENTS}

First, I would like to express my deepest gratitude to Dr.

Richard B. Forbes, my advisor, for his invaluable advice and encouragement throughout the course of this work. Secondly, my friend Peter Paquet deserves special thanks for his many contributions. The two of them represent the finest companionship out in the field that I have ever known.

Thanks are also extended to Dr. Robert O. Tinnin for his constructive criticism and patient consultation, to Dr. Quentin D. Clarkson for his kind assistance in statistical matters, to Dr. Richard R. Petersen for serving on my committee, to Ron Neilson for help in collecting tree density data, to Lynn Hockaden for doing the typing, and to Jane Lee and the members of my household for putting up with me during the writing of this thesis.

The work was supported by a grant from the U. S. Army Corps of Engineers, Portland District. 
TABLE OF CONTENTS

PAGE

ACKNOWLEDGEMENTS . . . . . . . . . . . . . . .

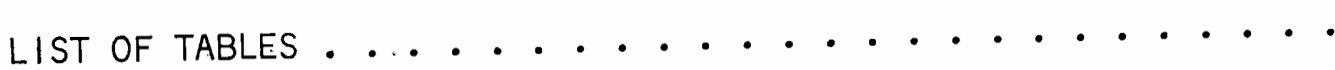

INTRODUCTION

MATERIALS AND METHODS ................. $\cdot \cdot$

Site Selection

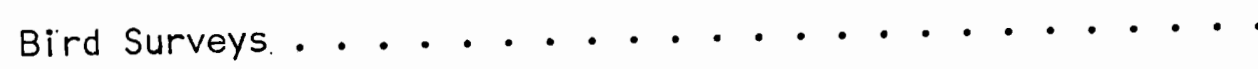

Plant Surveys .................. . .

Site Descriptions

Willamette River Area 1 . . . . . . . . .

Santiam River Area ...............

Willamette River Area. 2...........

Statistical Techniques ..............

Birds

Plants......................

Linear Regressions ..................

Bird Use of Revetments and the Effect of Clearing . . .

Comparison with Woodland Bird Species along the

Columbia River.................. 
PAGE

Conclusions

Research Recommendations ...............

REFERENCES CITED .................................... 46

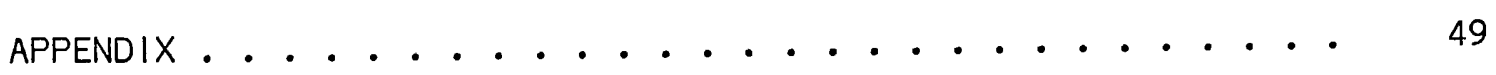




\section{LIST OF TABLES}

TABLE

PAGE

1 Average Dimensions of Bird Survey Areas in July 1975 . . 7

11 Summary of Total and Breeding Bird Use on Revetments . . 16

III Species Observed in Bird Survey Areas on Four

Uncleared Revetments April to July 1975 . . . .

IV Species Observed in Bird Survey Areas on Four

Cleared Revetments April to July 1975 . . . . .

$\checkmark \quad$ Species Exhibiting Breeding Behavior in Bird Survey

Areas on Cleared and Uncleared Revetments, April

to July 1975 . . . . . . . . . . . . .

VI Analysis of Canopy-cover, Density of Trees, and

Bordering Vegetation on Eight Bird Study Transects

in July and August 1975 . . . . . . . . . .

VII Correlation Coefficients ( $r$ Values) between Measures

of Bird Use and Measures of Effect of Clearing,

Tree Density, Canopy Cover, and Adjacent

Vegetation . . . . . . . . . . . . . .

VIII Bird Species Observed on Four Visits During Spring

and Summer at Six Riparian Woodland Areas on the

Lower Columbia River and Eight Revetments in the

Willamette Basin (Columbia River Data from OCWRU

(1976)) . . . . . . . . . . . . . 
IX Average Quotients of Similarity Resulting When Bird Species Found at Each of Six Riparian Woodlands are Compared Pair-wise with Each Other as Well as with Bird Species Found at Eight Revetments (Expressed in Percent and Placed in Descending Order) . . . . . . . . . . . . . . . 


\section{LIST OF FIGURES}

FIGURE

PAGE

1. Study Areas and Major Cities of the Lower Willamette

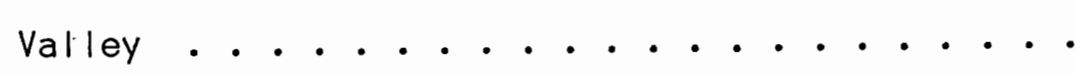

2. Diagram of a Revetment Showing Structural Features of

Concern in This Study (from Forbes et al. 1976). . 6

3. Completed Bird Survey Sheet . . . . . . . . . . . . 9

4. Bird Species Similarity to Riparian Woodland Regressed

Against Canopy Cover of Trees Greater Than

2 Meters . . . . . . . . . . . . . 


\section{INTRODUCTION}

One of the major threats to wildlife, including birds, is the continuing loss of suitable habitat. One type, riparian habitat, has received relatively little study with respect to bird use. A few published studies have shown riparlan habitats to be some of the richest, with respect to avifauna, in North America (Udvardy 1957; Carothers et al. 1974; Bottorff 1974; Oregon Cooperative Wildlife Research Unit (OCWRU) 1976).

Extensive riparian forests once covered much of the floodplain of the Willamette Valley of northwestern Oregon (Towle 1974). Through mancaused clearance of the land, only a small fraction of this forest remains; what is left continues to be removed (Towle 1974).

As the riparian forest is removed, the small patches that remain become increasingly important. Potential sites of at least some riparian habitat for birdlife are man-made structures called revetments.

Concerning revetments in the Willamette Valley, Forbes, Paquet, Willis, and I (1976) have written the following:

Over the past several decades, the Corps of Engineers has constructed more than 115 miles of rock revetments that serve to stabilize portions of the channels of Willamette Basin streams. The primary objective of this activity is to prevent the loss of land and property that results from major channel changes. Deposition of sediment among the rocks composing a revetment permits herbs, shrubs, trees, and associated wildlife to become established on revetments. Routine maintenance of revetments includes removal of debris and vegetation that may weaken a revetment or interfere with its inspection from a helicopter. . . The Corps' present maintenance policy stipulates the cutting at the revetment surface of blackberry vines and all woody growth 2 inches $(5 \mathrm{~cm})$ or more in 
diameter, or 6 feet $(1.8 \mathrm{M})$ or more in height. All revetment surfaces, including stone aprons, are to be cleared in this manner.

Therefore, although rock revetments provide potential habitat for wildlife, present maintenance policy restricts the development of such habitat. Several wildlife management agencies and environmental groups have expressed concern over revetment maintenance and its effect on wildlife communities and on the aesthetics of the river (U.S. Army Engineer District, Portland, Oregon (USAEDPO) 1975).

In July 1974 the U.S. Army. Engineer District, Portland, Oregon contracted Portland State University to study wildlife communities found on revetments and to determine the effect of present clearing practices on those communities. The investigators involved in the study were Dr. Richard Forbes, project leader, and three graduate students, Peter Paquet, Robert Willis, and I. In that study we found greater bird use of uncleared than cleared revetments, suggesting that present clearing practices negatively affect bird use. Some of the results of that study were presented in Forbes et al. (1976).

In this thesis, avifaunal data collected as part of the study above are used to further evaluate differences between cleared and uncleared revetments. The results reported previously are extended in several ways: (1) breeding bird use is reported in addition to total bird use; (2) a measure of vegetation adjacent to revetments is used in addition to the measures of vegetation on revetments; (3) differences between revetments are evaluated statistically; (4) correlation coefficients between measures of bird use and measures of vegetation are computed and evaluated statistically; and (5) some of the results are compared with results from a similar study. 
MATERIALS AND METHODS

\section{SITE SELECTION}

Field investigations began in July 1974 and were concluded in October 1975. Only data collected April through July 1975 are reported here. Six pairs of study sites at four study areas were under investigation for that entire period, but only five pairs are included here. The sixth pair, located on the Molalla River, was excluded for two reasons: (1) the Molalla revetments were considerably smaller than all the other revetments, and (2) because of natural channel changes after their construction, the Molalla revetments are no longer located on the active channel of the Molalla River.

Each study pair consisted of two study sites: a cleared site (revetment cleared in the summer of 1974) and an uncleared site (revetment sufficiently overgrown as to be considered for clearing in 1975 or 1976). The sites in a given area were in as close proximity to each other as possible. The areas and sites, by revetment name, are shown below. The site names used are those of the United States Army Corps of Engineers District, Portland, Oregon (1975).

\section{STUDY PAIRS}

STUDY AREA

Willamette River No. I Will lamette River No. 2 Willamette River No. 2 Santiam River Santiam River
Cleared Site

Stoutenberg

Upper Half Moon Bend Coon Creek Wickham

Wickham
Uncleared Site

Grand $\mid$ sland Half Moon Bend Half Moon Bend Tomasek Millar 
The locations of the study areas in relation to the major cities of the Lower Willamette Valley are shown in Figure 1. The five pairs of study sites are not completely independent. Wickham serves as the cleared site for both Tomasek and Millar. Half Moon Bend serves as the uncleared site for both Coon Creek and Upper Half Moon Bend.

\section{BIRD SURVEYS}

For purposes of this study, such terms as slope, apron, shoulder, length, and width of revetments require definition and are shown in Figure 2.

Bird survey areas were laid out as line transects along the length of the revetment. In most cases the line transect was 700 meters long. Both Tomasek and Grand Island were shorter than 700 meters and a transect length of 650 meters was used for those revetments. Placement of bird survey areas along the length of the revetments was largely determined by the location of access points (see Appendix for exact placement).

Line transects were chosen for two reasons. First, because of fluctuations in water level, the amount of slope exposed varied; therefore, the area of each study plot could not be controlled. Secondly, the revetments are small in area and oblong in shape, resulting in a large perimeter relative to area and an expected large "edge effect" (Odum 1971). Kendeigh (1944) suggests treating data as birds per unit length rather than per unit area when the forest edge is narrow or of uncertain width. The dimensions of the revetments studied were measured in July 1975 and are shown in Table 1. 


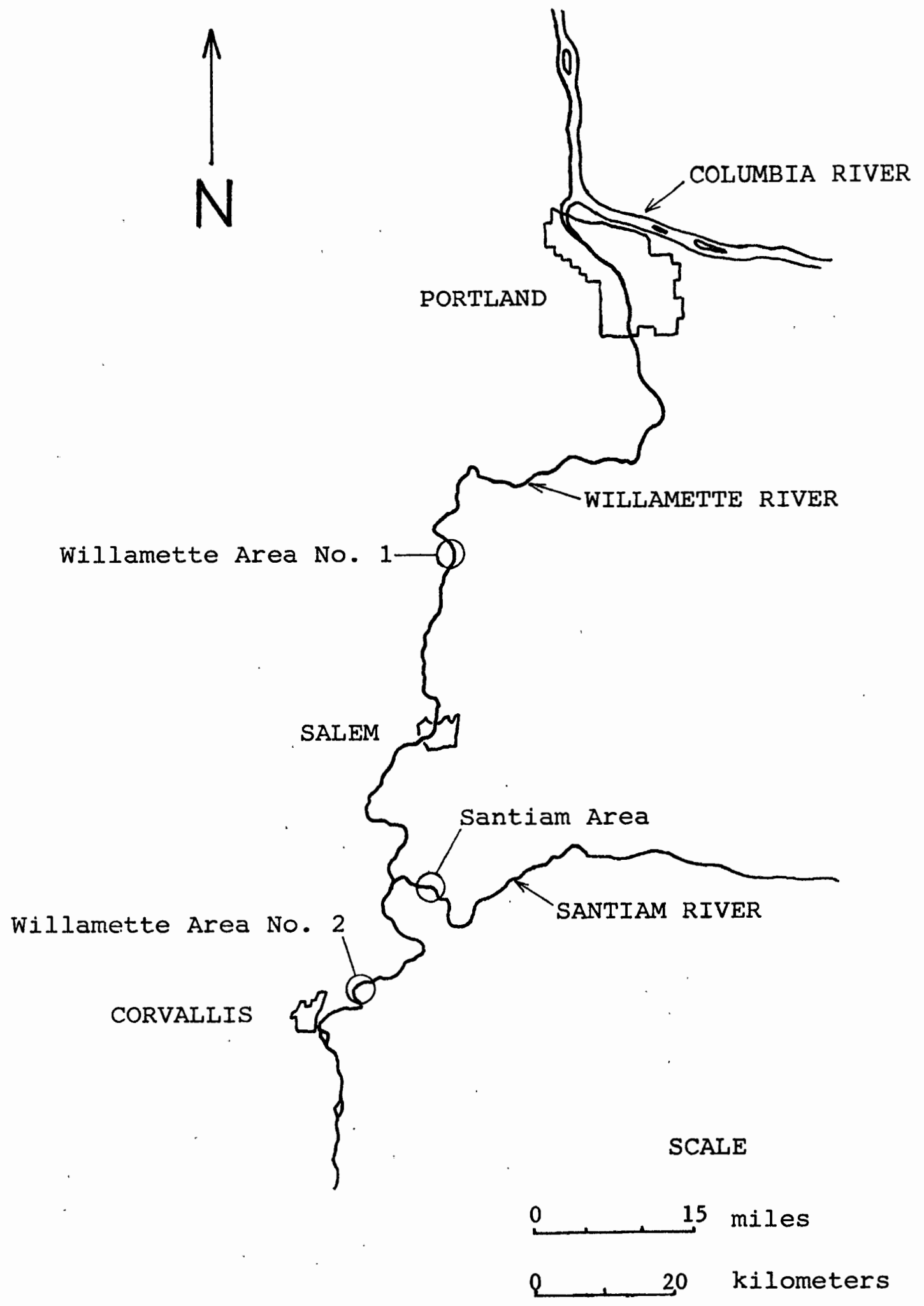

Figure 1. Study areas and major cities of the lower Willamette Valley. 
BACKGROUND

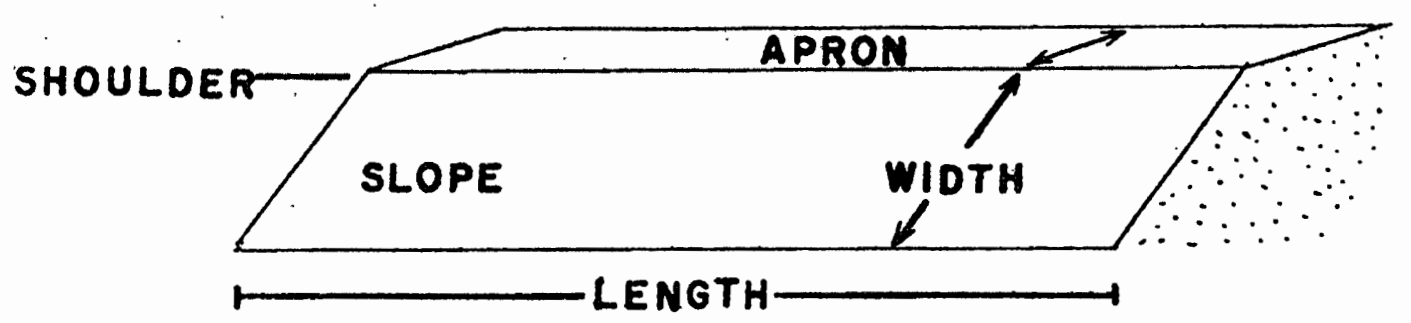

Figure 2. Diagram of a revetment showing structural features of concern in this study (from Forbes et a1. 1976). 
TABLE 1

AVERAGE DIMENSIONS OF BIRD SURVEY

AREAS IN JULY 1975

\begin{tabular}{|c|c|c|c|c|c|}
\hline Location & Nature & $\begin{array}{l}\text { Average } \\
\text { Width of } \\
\text { Apron }(\mathrm{m})\end{array}$ & $\begin{array}{l}\text { Average } \\
\text { Width of } \\
\text { slope (m) }\end{array}$ & $\begin{array}{c}\text { Length } \\
(\mathrm{m})\end{array}$ & $\begin{array}{c}\text { Area } \\
\text { (ha) }\end{array}$ \\
\hline Stoutenberg & Cleared & 7.1 & 9.4 & 700 & 1.15 \\
\hline Grand $\mid$ s $\mid$ and & Uncleared & 5.8 & 14.2 & 650 & 1.30 \\
\hline Tomasek & Uncleared & 1.4 & 9.5 & 650 & 0.71 \\
\hline Millar & Uncleared & 1.3 & 10.8 & 700 & 0.85 \\
\hline Wickham & Cleared & 2.5 & 11.0 & 700 & 0.94 \\
\hline Coon Creek & Cleared & 0.2 & 11.5 & 700 & 0.82 \\
\hline $\begin{array}{l}\text { Half Moon } \\
\text { Bend }\end{array}$ & Uncleared & 5.0 & 11.4 & 700 & 1.15 \\
\hline $\begin{array}{l}\text { Upper Half } \\
\text { Moon }\end{array}$ & Cleared & 2.6 & 13.1 & 700 & 1.10 \\
\hline Average Area & of all Cle & red Revetm & & & 1.00 \\
\hline Average Area & of All Unc & eared Revet & ents & & 1.00 \\
\hline
\end{tabular}

Each group of study sites in a study area was surveyed simultaneously for three hours once each month. Effects of differences in weather and time of day are thereby minimized. The surveys were begun before sunrise, as soon as light was sufficient for bird.identification. An investigator was stationed at each of the two or three study sites in a study area. The investigators were of approximately equal ability in identification of birds. Nonetheless, investigators were placed at different revetments each month in order to allow for any differences in fleld identification ability.

The bird census consisted of approximately the first hour of the bird survey. During this first hour, the investigator would walk the 
line transect in one direction and could be reasonably certain that no individuals were counted twice.

The remaining two hours of the survey were spent either walking or stationary. The purpose of the stationary periods was to detect less conspicuous birds. Among more conspicuous species, however, individuals were often counted more than once during the entire threehour period.

Bird survey data sheets were constructed and an example is shown in Figure 3. Throughout the study, singing males, active nests, parents feeding young, etc. were noted as indications of breeding pairs. For a discussion of the problems associated with using singing males as indicators, see Emlen (1971).

Binoculars and spotting scopes were used to aid bird identification. Bird names used are those standardized and listed with scientific names by the American Ornithologists' Union (AOU) Checklist Committee (AOU 1957; AOU 1973).

\section{PLANT SURVEYS}

The density of trees greater than $2 \mathrm{~m}$ was determined for all bird survey areas in July 1975. On all revetments but Tomasek and Millar an absolute density was obtained by counting every tree greater than $2 \mathrm{~m}$ within each study area. At Tomasek and Millar, where the density of trees was too great for counting every tree to be practical, several rectangular quadrats were established systematically and every tree taller than $2 \mathrm{~m}$ was counted within each quadrat. Each quadrat 


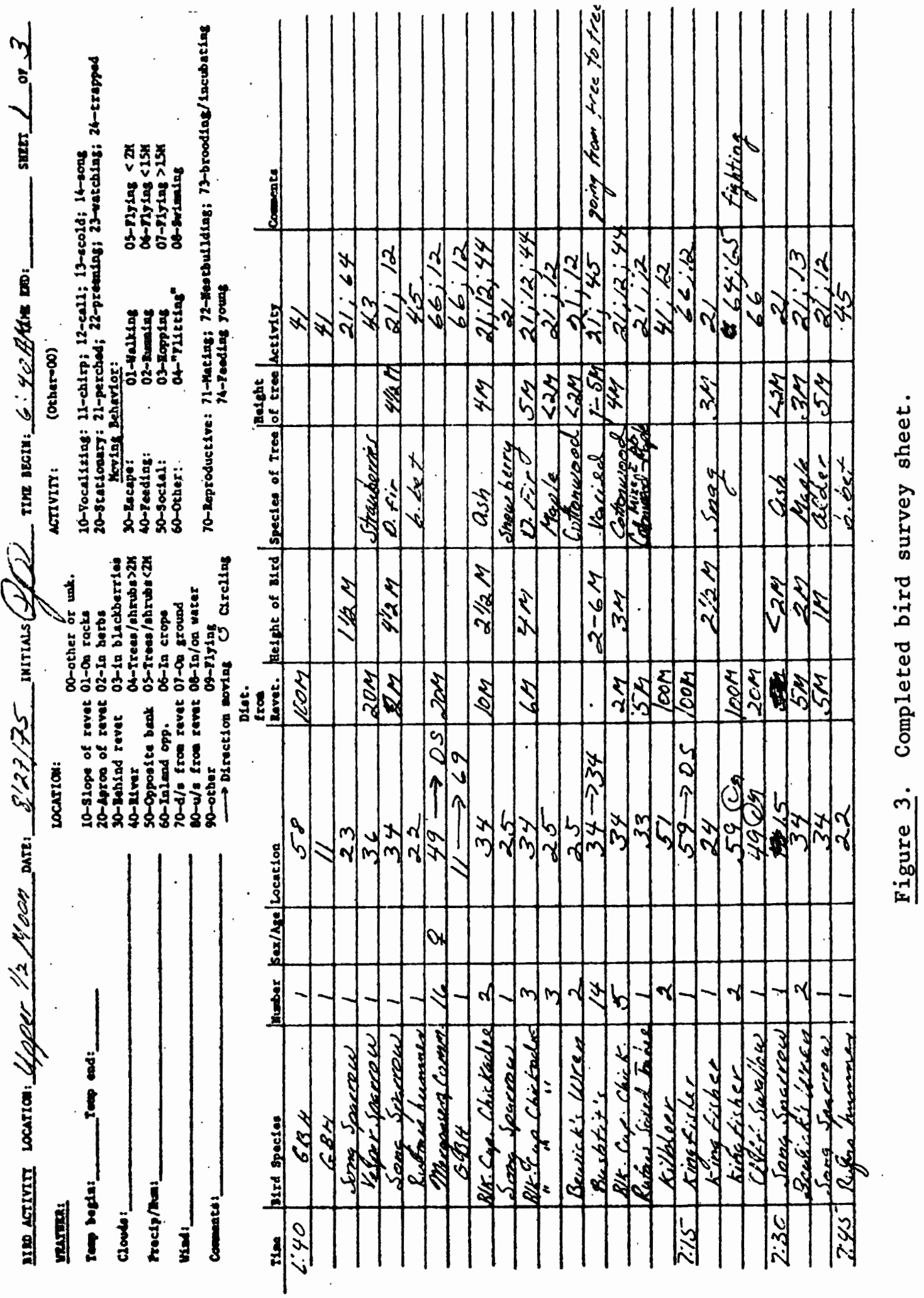


extended $25 \mathrm{~m}$ along the length of the revetment and encompassed the combined width of the slope and apron.

A study of canopy cover in bird survey areas was undertaken in August 1975 on six revetments: Millar, Tomasek, Wickham, Half Moon Bend, Upper Half Moon Bend, and Coon Creek. Canopy cover was estimated using the techniques of Daubenmire (1959). The Daubenmire cover classes we employed are shown in Table VI. Woody plants were divided into four layers; all herbaceous plants were included as a fifth layer. The surface of the revetment was also described as percent rock, silt, and debris using Daubenmire cover classes (see Table VI).

For all quadrats, the length of the side parallel to the river was $5 \mathrm{~m}$. Within bird survey areas, separate apron and slope quadrats were established. The length of the quadrat side perpendicular to the flow of the river was the entire apron width for the apron quadrats and the entire slope width for slope quadrats.

Rectangular quadrats considerably larger than those suggested by Daubenmire were chosen in order to include gradations in vegetation moving away from the waterline. I believe that canopy cover on revetments can be consistently estimated within quadrats as large as $126 \mathrm{~m}^{2}$.

Quadrats were laid out every $50 \mathrm{~m}$ along the length of the revetment. Apron quadrats were laid out only when the apron width measured greater than $2 \mathrm{~m}$. Approximately 10 percent of each bird survey area was sampled.

An average cover class value for an entire bird survey area was obtained using the methods of Daubenmire (1959) with one modification. Because of the differences in quadrat size, cover class values for each 
quadrat were weighted according to the area of the quadrat rather than being treated equally.

The vegetation in areas bordering revetments was not specifically measured. Approximate values for percent of bird transects bordered by dense natural cover were obtained using maps constructed by the investigators. Dense natural cover was arbitrarily defined as vegetation containing woody plants and/or blackberries within $10 \mathrm{~m}$ of revetments and at least $5 \mathrm{~m}$ deep. .

The scientific names used for plants are those of Hitchcock and Cronquist (1973).

\section{SITE DESCRIPTIONS}

All revetments included in this study ended in dense riparian vegetation consisting largely of Populus trichocarpa, Acer macrophyllum, Salix sp., and often Rubus sp. In general, by the summer of 1975, vegetation on revetments cleared during 1974 consisted largely of herbaceous plants with relatively little woody vegetation present. Average inclination of the revetment slopes was $25^{\circ}$ plus or minus $3^{\circ}$.

Prior to 1974 maintenance of most revetments consisted of occasional spraying with herbicides $(2,4,5-T$ and $2,4-D)$. The schedule of spraying varied. On all revetments cleared in 1974, even though blackberry clumps were removed and the remaining cane stumps sprayed with herbicide, healthy new growth from cane stumps was observed during the spring and summer of. 1975.

Individual descriptions of revetments having unique characteristics are included below. The descriptions are arranged from downstream 
to upstream on the river (i.e., north to south). Additional informat tion on all revetments studied can be found in the Appendix.

Willamette River Area 1

Grand $\mid$ sland is unique among the revetments studied in that it was hand laid. This type of construction results in a relatively smooth surface compared with other revetments. Grand Island had the least vegetation of all the uncleared revetments, even though it is the oldest. It was also noted that the deposition of silt was considerably less than on other revetments. It is suspected that the relative lack of vegetation is due to either unusually effective spraying or the lack of silt or both.

Santiam River Area

Tomasek is relatively heavily vegetated along almost the entire revetment. Although no trees on the revetment were taller than 15 meters, some approached that height and many trees are in the 5 to 15 meter height class.

Millar was mainly built as an emergency revetment in 1948 and it has never been maintained by spraying or clearing. Consequently, approximately 500 meters of the bird survey area was heavily vegetated with Populus trichocarpa taller than 15 meters and a dense understory. The remaining 200 meters had also not been maintained, but was repaired after 1948. Except for some scattered trees, most of the cover in this area consisted of dense Rubus sp.

Wickham was cleared in 1974, but a number of trees greater than $2 \mathrm{~m}$ in height were apparently overlooked by the contractor. Nonetheless, 
by 1975 the vegetation consisted mainly of herbaceous plants. Wickham is unusual in that, since construction of the revetment, the river has deposited gravel at the foot of the revetment along approximately 50 meters of the bird survey area. This gravel has allowed a small thicket (less than 500 square meters) of Salix sp. to grow up in the river channel itself. Although many are taller than 2 meters, these willows were not cleared in 1974 because they did not actually occur on the revetment itself. Wickham is also unusual in that a dike has been built behind the revetment and extends along its entire length.

\section{Willamette River Area 2}

Half Moon Bend was the most heterogeneous of the uncleared revetments. Beginning at the upstream end of the bird survey area, the first 80 meters consisted of a dense thicket of Acer macrophyllum less than 10 meters tall. Most of the rest of the bird survey area was mixed deciduous with many clumps of blackberries. The downstream approximately 200 meters had relatively less woody vegetation and more herbaceous vegetation. None of the trees on the revetment approached 15 meters in height.

\section{STATISTICAL TECHNIQUES}

Differences between cleared and uncleared revetments were tested for statistical significance using paired t-tests (assuming 4 degrees of freedom). I realize that because the 5 pairs of revetments are not entirely independent, the possible interpretations of the results are limited. 
Linear correlation coefficient's between variables were computed with the help of the Portland State University statistical package on the Harris 200. Specifically, the multiple regression program (MREGR) converted for this computer from the standard REGR program published by IBM (1957), was used.

Independent variables for the regressions were constructed using vegetational data collected in this study. The overall effect of vegetational clearing practices was expressed as a nominal variable with uncleared revetments receiving a score of zero and cleared revetments a score of one. Canopy cover in one or more vegetation layers was expressed as the sum of the Daubenmire cover class midpoint values for the appropriate layers (see Table VI). It should be noted that the possible interpretations of the correlations are limited because the revetments were not chosen randomly. 


\section{RESULTS}

BIRDS

A summary of all bird use, including breeding bird use, of study areas is shown in Table 11. The data generally show a marked difference between cleared and uncleared revetments. These differences are more striking at some areas than others (e.g., the differences at Willamette Area No. I are consistently less).

To test the significance of the differences, the revetments were treated as five independent matched pairs (see "Methods"). The results of paired t-tests are shown at the bottom of Table II. Except for average number of individuals per census, all differences were significant at the .02 level or better.

The species observed on each revetment are shown in Tables 111 and IV. On uncleared sites (Table III), 46 species were observed, 36 of them more than once and 32 on more than one revetment. On cleared revetments (Table IV), only 32 species were observed, 20 of them more than once, and 15 on more than one revetment.

Only one species, the song sparrow, was sighted on all 8 revetments, both cleared and uncleared. In fact, song sparrows were observed on bird survey areas in all but one of the 32 bird surveys done. In addition to the song sparrow, on the four uncleared sites, 8 species were observed at least once at each of the revetments: brownheaded cowbird, black-capped chickadee, common yellowthroat, 


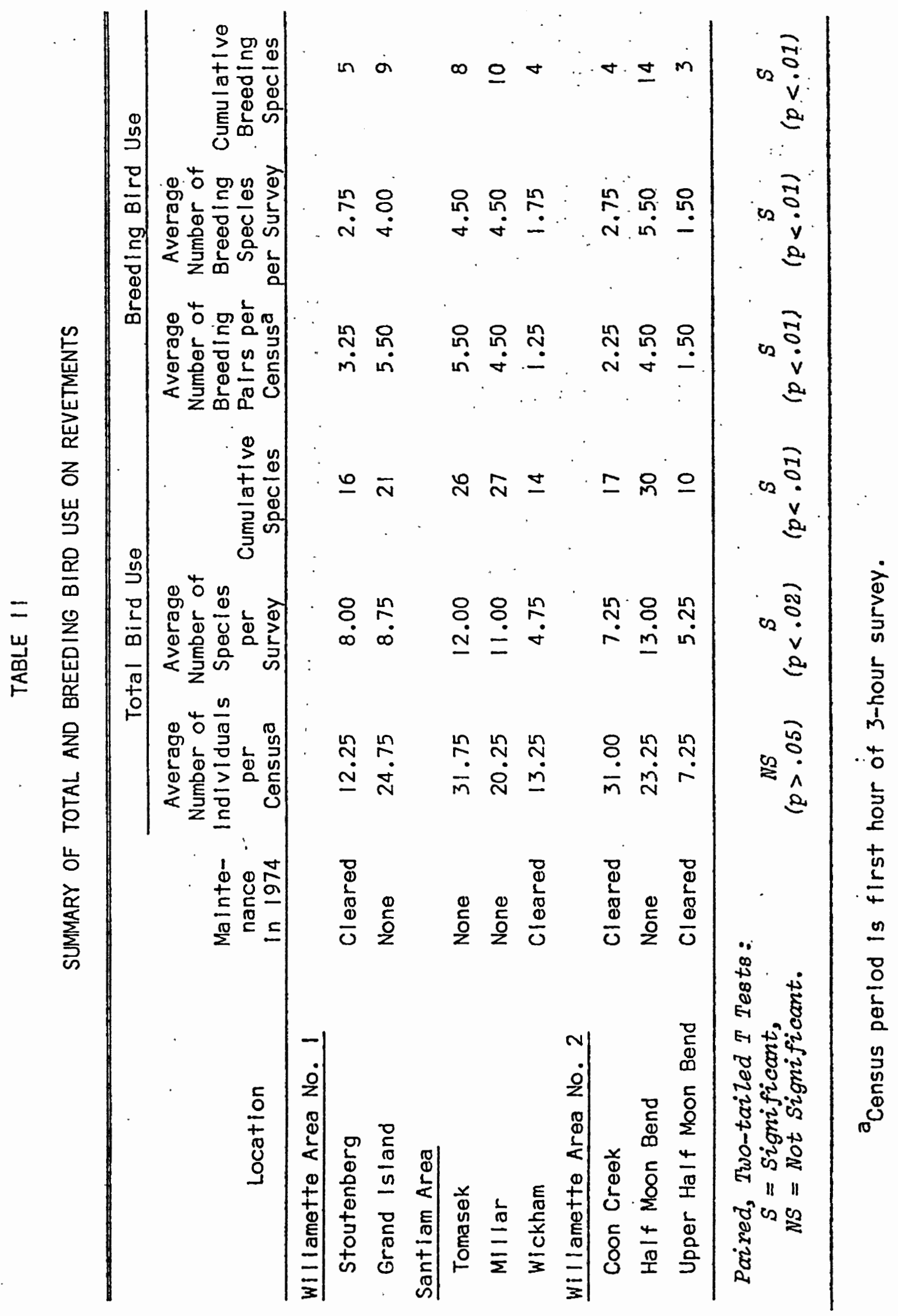


TABLE $\|1\|$

SPECIES OBSERVED IN BIRD SURVEY AREAS ON FOUR UNCLEARED REVETMENTS APRIL TO JULY 1975

\begin{tabular}{|c|c|c|c|c|c|}
\hline \multirow[b]{2}{*}{ Bird Specie's } & \multicolumn{5}{|c|}{ Number of Surveys Observed } \\
\hline & $\begin{array}{l}\text { Grand } \\
\text { Island }\end{array}$ & Tomasek & Millar & $\begin{array}{l}\text { Half } \\
\text { Moon } \\
\text { Bend }\end{array}$ & $\begin{array}{c}\text { Tofal } \\
\text { (Out } \\
\text { of }(6) \\
\end{array}$ \\
\hline Great Blue Heron & 1 & 2 & -- & 1 & 4 \\
\hline Green Heron & 1 & -- & -- & -- & 1 \\
\hline California Quail & 2 & -- & 1 & 1 & 4 \\
\hline Sandpiper Species & -- & -- & -- & 2 & $\begin{array}{l}2 \\
2\end{array}$ \\
\hline Rufous Hummingbird & 1 & 1 & -- & -- & \\
\hline $\begin{array}{l}\text { Belted Kingfisher } \\
\text { Common Flicker }\end{array}$ & 1 & 1 & -- & 2 & 4 \\
\hline Common Flicker & 1 & 1 & 1 & 1 & 4 \\
\hline Downy Woodpecker & -- & -- & 2 & -- & 2 \\
\hline Western Wood Pewee & -- & -- & 3 & 1 & 4 \\
\hline Violet-green Swallow & -- & - & -- & 1 & 1 \\
\hline Tree Swallow & - & 1 & 1 & -- & 2 \\
\hline Barn Swallow & 1 & 1 & - & - & 2 \\
\hline Cliff Swallow & -- & -- & -- & 1 & 1 \\
\hline Common Crow & -- & - & 1 & -- & 1 \\
\hline Black-capped Chickadee & 2 & 1 & 2 & 1 & 6 \\
\hline Common Bushtit & -- & 2 & -- & -- & 2 \\
\hline Bewick's Wren & -- & -- & 1 & 2 & 3 \\
\hline American Robin & 2 & 3 & 2 & 3 & 13 \\
\hline Hermit Thrush & -- & 1 & 1 & - & 2 \\
\hline Swainson's Thrush & -- & 2 & 3 & 1 & 6 \\
\hline Golden-crowned kinglet & -- & 1 & -- & -- & 1 \\
\hline Ruby-crowned kinglet & $-\dot{-}$ & 2 & 1 & -- & 3 \\
\hline Cedar Waxwing & -- & 2 & 2 & 2 & 6 \\
\hline Starling & 1 & -- & 1 & -- & 2 \\
\hline Warbling Vireo & -- & 1 & 1 & 1 & 3 \\
\hline Orange-crowned Warbler & -- & -- & 1 & 1 & 2 \\
\hline Yellow Warbler & -- & 1 & 2 & -- & 3 \\
\hline Yellow-rumped Warbler & - & 1 & -- & 1 & 2 \\
\hline Common Yellowthroat & 2 & 2 & 1 & 1 & 6 \\
\hline Yellow-breasted Chat & -- & -- & 1 & -- & 1 \\
\hline Wilson's Warbler & -- & -- & 1 & -- & 1 \\
\hline Red-winged Blackbird & 1 & -- & -- & -- & 1 \\
\hline Brewer's Blackbird & 2 & -- & -- & 1 & 3 \\
\hline Brown-headed Cowbird & 2 & 2 & 2 & 3 & 9 \\
\hline Black-headed Grosbeak & 1 & 2 & 1 & 1 & 5 \\
\hline
\end{tabular}


TABLE $|1|-$ - Continued

\begin{tabular}{|c|c|c|c|c|c|}
\hline \multirow[b]{2}{*}{ Bird Species } & \multicolumn{5}{|c|}{ Number of Surveys Observed } \\
\hline & $\begin{array}{l}\text { Grand } \\
\mid \text { sland }\end{array}$ & Tomasek & Millar & $\begin{array}{l}\text { Half } \\
\text { Moon } \\
\text { Bend }\end{array}$ & $\begin{array}{r}\text { Total } \\
\text { (Out } \\
\text { of } 16) \\
\end{array}$ \\
\hline Lazuli Bunting & -- & -- & - & 3 & 3 \\
\hline Evening Grosbeak & -- & -- & -- & 1 & $i$ \\
\hline Purple Finch & -- & -- & -- & 1 & 1 \\
\hline American Goldfinch & -- & 3 & 2 & 3 & 8 \\
\hline Rufous-sided Towhee & 3 & 4 & 3 & 4 & 14 \\
\hline Savannah Sparrow & 1 & 1 & 1 & 1 & 4 \\
\hline Vesper Sparrow & 1 & 4 & -- & 3 & 8 \\
\hline Dark-eyed Junco & -- & -- & 1 & 1 & 2 \\
\hline White-crowned Sparrow & 4 & -- & -- & 2 & 6 \\
\hline Golden-crowned Sparrow & 1 & 1 & -- & -- & 2 \\
\hline Song Sparrow & 4 & 4 & 4 & 4 & 16 \\
\hline Total Number of Species & 21 & 26 & 27 & 30 & 46 \\
\hline $\begin{array}{l}\text { Number of Species Observed } \\
\text { During More Than One Survey }\end{array}$ & & & & & 36 \\
\hline $\begin{array}{l}\text { Number of Species Seen on } \\
\text { More Than One Revetment }\end{array}$ & & & & & 32 \\
\hline
\end{tabular}

TABLE IV

SPECIES OBSERVED IN BIRD SURVEY AREAS ON FOUR CLEARED REVETMENTS APRIL TO JULY 1975

\begin{tabular}{|c|c|c|c|c|c|}
\hline \multirow[b]{2}{*}{ Bird Species } & \multicolumn{5}{|c|}{ Number of Surveys Species Observed } \\
\hline & $\begin{array}{l}\text { Stout- } \\
\text { enberg }\end{array}$ & Wickham & $\begin{array}{l}\text { Upper } \\
\text { Half } \\
\text { Moon }\end{array}$ & $\begin{array}{r}\text { Coon } \\
\text { Creek }\end{array}$ & $\begin{array}{c}\text { Total } \\
\text { (Out } \\
\text { of } 16 \\
\text { Surveys) }\end{array}$ \\
\hline Great Blue Heron & 4 & 1 & 3 & 3 & 11 \\
\hline Green Heron & -- & 2 & -- & -- & 2 \\
\hline Mallard & 1 & -- & -- & -- & 1 \\
\hline Turkey Vulture & -- & 1 & -- & 1 & 2 \\
\hline California Quail & 3 & -- & -- & -- & 3 \\
\hline
\end{tabular}


TABLE IV--Continued

\begin{tabular}{|c|c|c|c|c|c|}
\hline \multirow[b]{2}{*}{ Bird Species } & \multicolumn{5}{|c|}{ Number of Surveys Species Observed } \\
\hline & $\begin{array}{l}\text { Stout- } \\
\text { enberg }\end{array}$ & Wickham & $\begin{array}{l}\text { Upper } \\
\text { Half } \\
\text { Moon }\end{array}$ & $\begin{array}{r}\text { Coon } \\
\text { Creek }\end{array}$ & $\begin{array}{c}\text { Total } \\
\text { (Out } \\
\text { of } 16 \\
\text { Surveys) }\end{array}$ \\
\hline Ring-necked Pheasant & 2 & -- & -- & -- & 2 \\
\hline Sandpiper Species & 2 & 1 & 3 & 1 & $\overline{7}$ \\
\hline Rufous Hummingbird & 1 & - & 1 & -- & 2 \\
\hline Belted Kingfisher & -- & -- & -- & 1 & 1 \\
\hline Common Flicker & -- & 1 & -- & 1 & 2 \\
\hline Violet-green Swallow & -- & -- & -- & 1 & 1 \\
\hline Cliff Swallow & -- & -- & -- & 1 & 1 \\
\hline Scrub Jay & 1 & -- & -- & -- & 1 \\
\hline Common Crow & 2 & - & -- & -- & 2 \\
\hline Common Bushtit & 1 & -- & -- & -- & 1 \\
\hline Bewick's Wren & -- & -- & -- & 1 & 1 \\
\hline American Robin & -- & 1 & 3 & -- & 4 \\
\hline Hermit Thrush & -- & -- & 1 & -- & 1 \\
\hline Cedar Waxwing & -- & 1 & -- & -- & 1 \\
\hline Common Yell lowthroat & 3 & -- & -- & 1 & 4 \\
\hline Red-winged Blackbird & -- & 2 & - & 2 & 4 \\
\hline Brewer's Blackbird & - & 2 & -- & 1 & 3 \\
\hline Brown-headed Cowbird & 2 & -- & 1 & 2 & 5 \\
\hline Black-headed Grosbeak & - & 1 & -- & -- & 1 \\
\hline Lazuli Bunting & -- & 1 & -- & -- & 1 \\
\hline American Goldfinch & -- & 1 & 1 & 4 & 6 \\
\hline Rufous-sided Towhee & 1 & 1 & - & 1 & 3 \\
\hline Savannah Sparrow & - & -- & -- & 2 & 2 \\
\hline Vesper Sparrow & 2 & -- & 1 & 2 & 5 \\
\hline Dark-eyed Junco & 1 & -- & -- & - & 1 \\
\hline White-crowned Sparrow & 2 & -- & 4 & -- & 6 \\
\hline Song Sparrow & 4 & 3 & 4 & 4 & 15 \\
\hline Total Number of Species & 16 & 14 & 10 & 17 & 32 \\
\hline $\begin{array}{l}\text { Number of Species Observed } \\
\text { at More Than One Survey. }\end{array}$ & & & & & 20 \\
\hline $\begin{array}{l}\text { Number of Species Observed } \\
\text { on More Than One Revetment }\end{array}$ & & & & & 15 \\
\hline
\end{tabular}


rufous-sided towhee, savannah sparrow, American robin, common flicker, and black-headed grosbeak. On cleared sites only 2 specjes besides the song sparrow--sandpipers and great blue herons--were sighted at all four revetments.

Species observed exhibiting breeding behavior on revetment bird study areas are listed in Table V. A total of 18 such species were noted on uncleared revetments, 14 of them more than once and 12 on more than one revetment. Only 9 species were sighted on cleared revetments, 7 of them more than once and 5 on more than one revetment.

The only breeding species found on all four cleared revetments was the ubiquitous song sparrow. On all four uncleared revetments, song sparrows, rufous-sided towhees, brown-headed cowbirds, and common yellowthroats were found exhibiting behavior associated with breeding.

\section{PLANTS}

Photographs of the revetments can be found in complete copies of Forbes et al. (1976). The results of physiognomic analyses of bird study areas are summarized in Table VI. More detailed information can be found in the Appendix.

As one would expect, the cleared revetments lack Daubenmire cover class layers $\mathrm{WI}$ and $\mathrm{W} 2$, and show poor representation of plants in the W3 layer. The uncleared revetments show great variation in both the number of layers present and the amount of cover within each layer.

There is also great variation in the density of trees greater than $2 \mathrm{~m}$ from revetment to revetment. The uncleared revetments range from 220 to 1,000 trees per hectare and the cleared revetments range from 


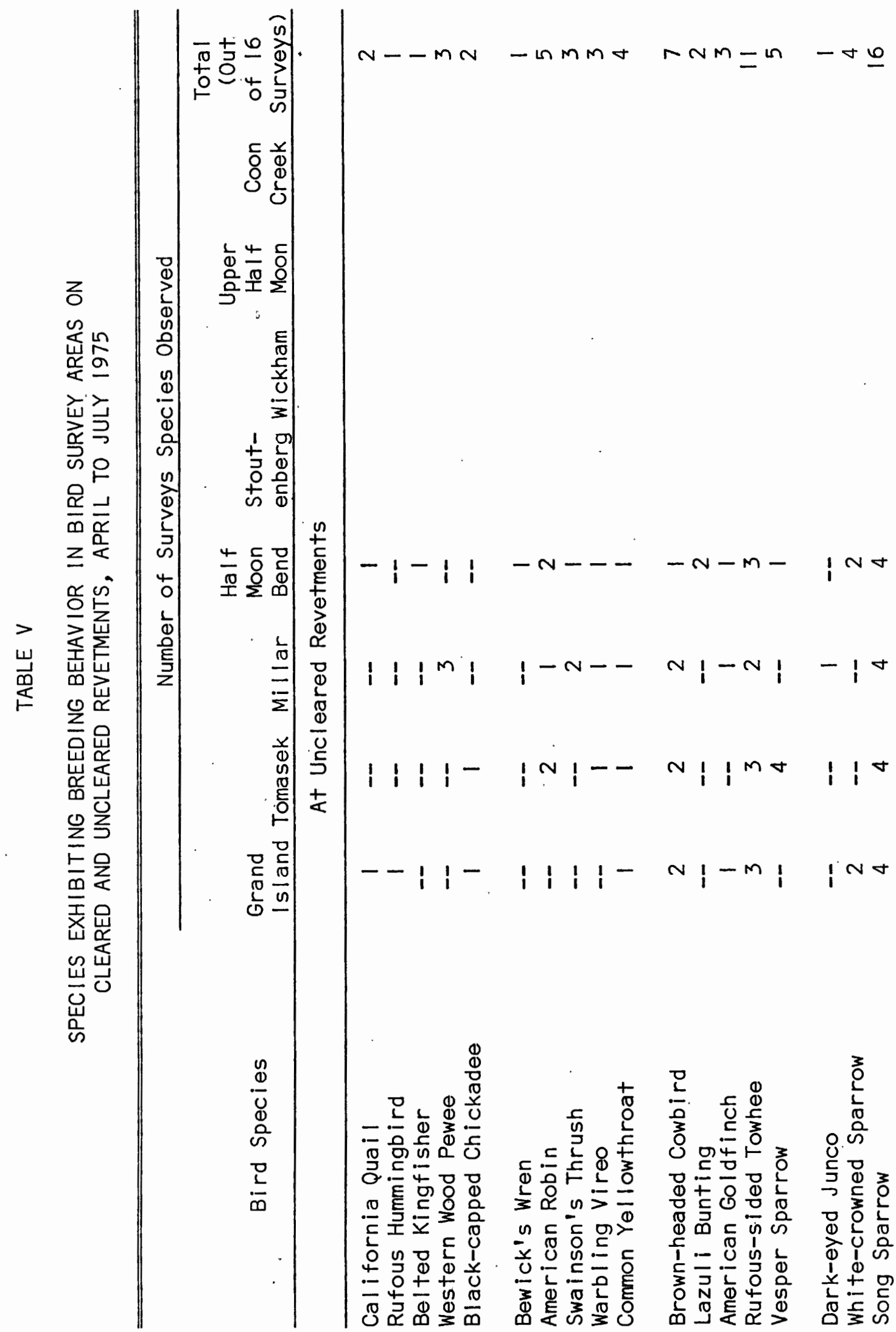




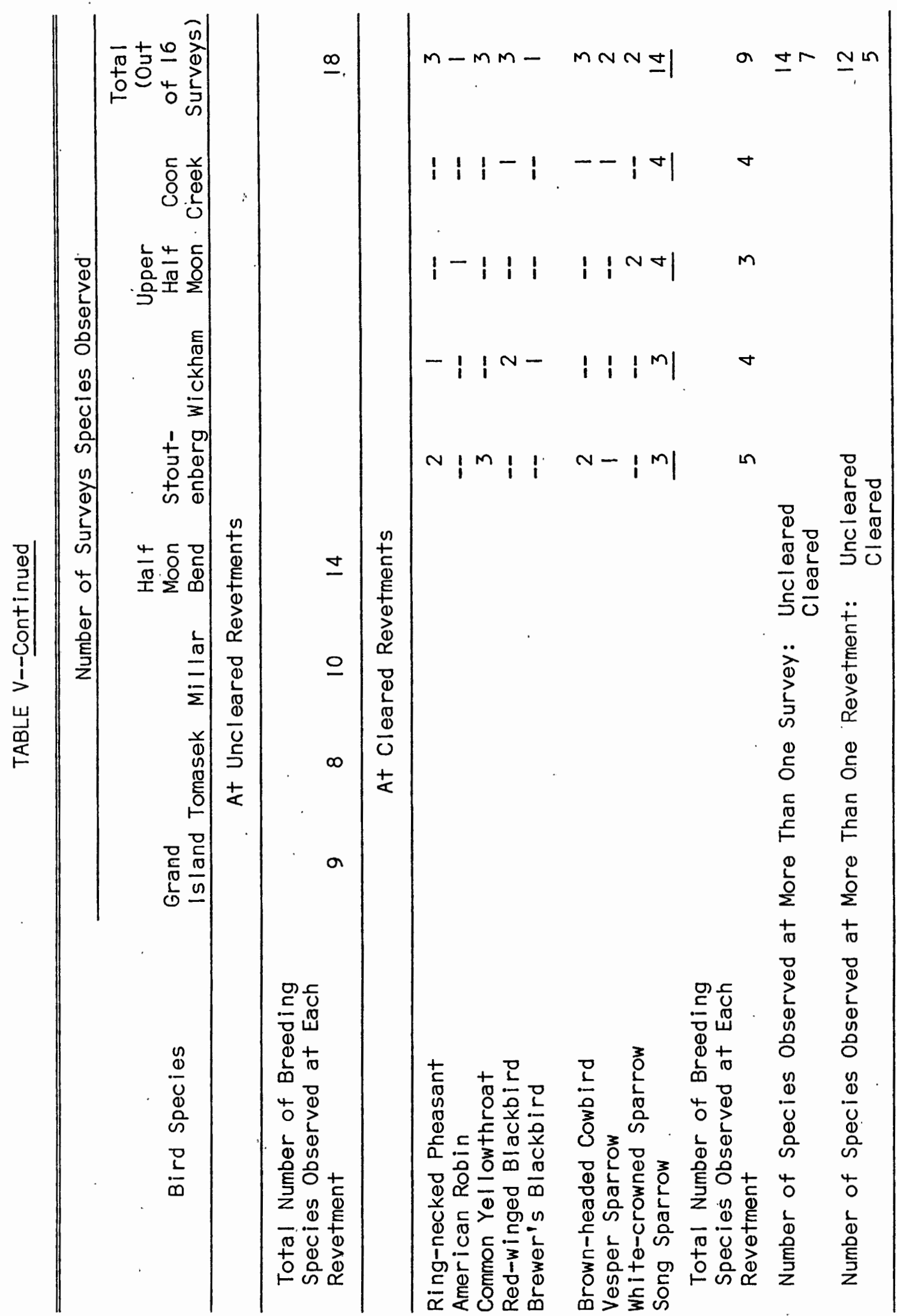




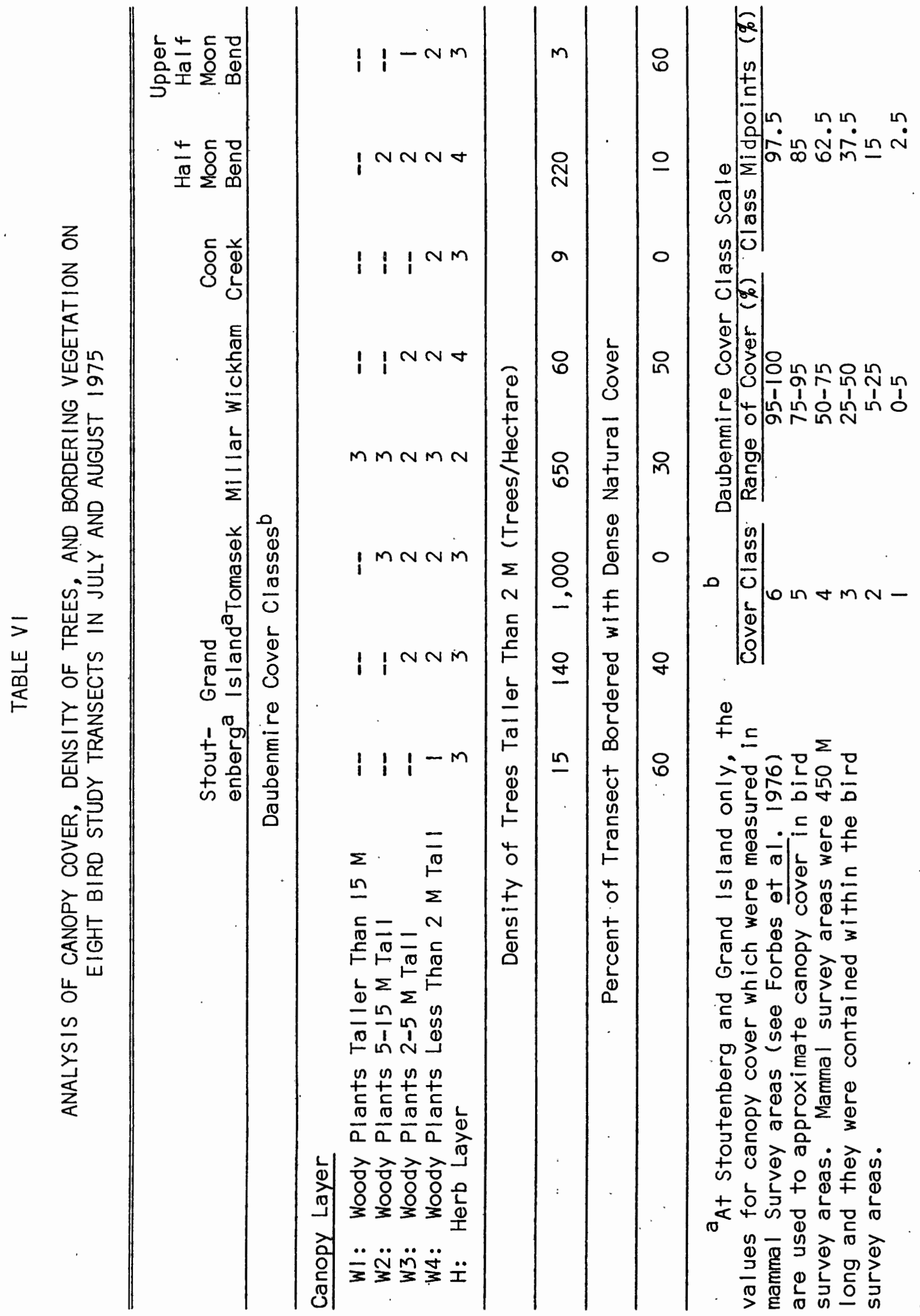


3 to 60 trees per hectare. It should be noted that the vegetational analyses were conducted in July and August 1975, so the densities of trees taller than $2 \mathrm{~m}$ presumably includes some individuals that were too small to be cut during the 1974 clearing operations.

The percent of bird survey transects bordered with dense natural cover varies from 0 to 60 . The percent values represent a rough estimate of bordering vegetation that could influence bird use of the revetment. For uncleared revetments, the average percent of transect bordered is 42.5 percent, while it is only 20 percent for uncleared revetments.

This result raises the interesting possibility that at least some differences in bird use of revetments may be reflecting differences in vegetation bordering the revetment, rather than differences in vegetation on the revetment. In addition, the possibility exists that the effects of clearing and the effects of vegetation bordering the revetment are confounded and inseparable. Linear regression was used to investigate these possibilities.

\section{LINEAR REGRESSIONS}

In order to determine which of the factors measured correlated best with data from bird survey areas, the revetments were treated as eight randomly selected samples for the purposes of linear regression analysis (see "Methods").

Each of the six measures of avifaunal use shown in Table 11 was used as the dependent variable in different regressions. Eight 
different independent, variables were used for a total of 48 regressions. The resultant correlation coefficients are shown in Table VII.

Five of the six measures of bird use correlated best with the nominal variable expressing whether or not the revetment had been cleared in 1974 (all five correlations significant at the .01 level). Several correlations of bird use with measures of vegetation, al though not as high as those with the clearance nominal variable, were also statistically significant. The sixth measure of bird use, average number of individuals per census; was found to correlate significantly only with percent of transect bordered by dense natural vegetation (correlation significant at the .01 level).

Each dependent variable was regressed pair-wise against the others (coefficients are given in the Appendix). As one might expect, the various measures of vegetation correlate highly with each other as well as with, the nominal variable expressing vegetation clearing. What is of special interest is the correlation between the clearance nominal variable and the percent of transect bordered by dense natural cover. The relatively low and statistically non-significant correlation of .4750 suggests that these two measures are not confounded and their effects in this study are at least partially separable. 


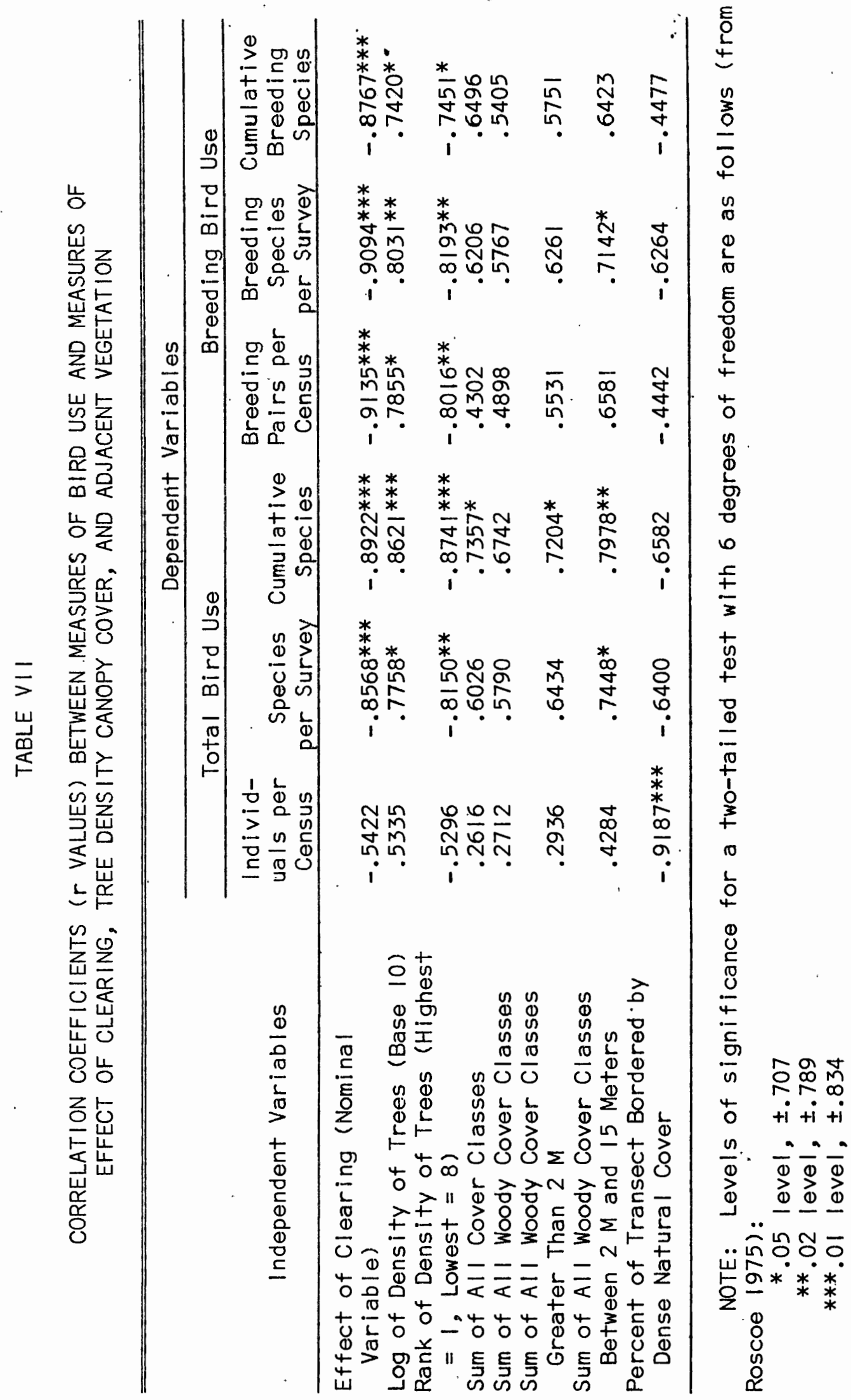




\section{BIRD USE OF REVETMENTS AND \\ THE EFFECT OF CLEARING}

The direct effect on revetments of present clearing practices is to reduce vegetational and physiognomic diversity. Plant succession is returned to the pioneer weed stage (Benton and Werner 1972). The visual effect of clearing is heightened by the fact that when a bank is protected, intensive agriculture may be practiced right up to the apron of the revetment. An uncleared revetment may harbor the only woody plants along a considerable length of stream bank.

Wickham, Tomasek, and Millar display three strikingly different seral stages along a $7,000 \mathrm{~m}$ length of stream bank. Wickham, having been cleared in 1974, had only a few trees on it in the summer of 1975 (Table VI). Of the trees present, some were ignored or overlooked by the clearing contractor and should have been removed. Tomasek has high densities of Populus trichocarpa and Salix sp.--fast-growing, suntolerant trees characteristic of the intermediate tree successional stage (Benton and Werner 1972). Millar is vegetated with numerous Populus trichocarpa and Salix sp. in the WI (taller than 15 meters) and W2 (5-15 meters tall) layers. However, the W2, W3, W4 woody plants are diverse, with such species as Alnus rubra, Eraxinus latifolia, and Acer macrophyllum also common. In fact, young F. latifolia are more common 
than young trees of any other species, suggesting a possible trend in succession on revetments.

Bird use of revetments also appears to be affected by the present clearing practices. All measures I used showed lower bird use on cleared revetments. Moreover, the actual differences in bird use between cleared and uncleared revetments are likely to be even greater because the screening effect of vegetation on uncleared revetments reduces the visibility of birds.

The results of this study indicate that the primary factor affecting the difference in bird use is the reduced vegetational and physiognomic diversity on cleared revetments. This conclusion is based on knowledge of the life history of the bird species involved as well as the correlations with measures of vegetation.

First, the logarithm of density of trees correlates well with most measures of bird use. This indicates that trees are important determinants of bird use, but that the addition of equal numbers of trees to the habitat gives smaller and smaller increases in bird use. However, without knowledge of the life history of birds, one could argue that the correlations are merely coincidental.

A comparison of Tables $1 / 1$ and IV shows that, of the bird species found commonly on uncleared revetments, many are species that require trees for feeding or nesting (e.g., black-capped chickadee, American robin, black-headed grosbeak, cedar waxwing, and common flicker). Several species which do not require trees for feeding or nesting, but which require dense cover, were seen only or largely on uncleared revetments (e.g., California quall, common yellowthroat, and rufous-sided 
towhee). On the other hand, birds found commonly only on cleared revetments are largely those that feed on open stream banks (e.g., sandpipers, great blue heron). The birds found often on both cleared and uncleared revetments are usually ground-herb-shrub species (e.g., song sparrow, American goldfinch). It is worth noting that many of the birds deemed favorable in insect control (swallows, chickadees, warblers, etc.) and one game species (California quail) are closely associated with uncleared revetments as opposed to cleared ones.

Besides vegetation on the revetment itself, another probable factor affecting bird use of an area as smali and oblong as a revetment, is the vegetation bordering the revetment. One measure of bird use--individuals per census--showed a significant negative correlation with rough estimates of background vegetation. However, this measure of bird use is probably the one most affected by sample size. The high average number of individuals per census at Coon Creek illustrates this point. During the July census at Coon Creek, a total of 82 individual birds were sighted using the revetment during the first hour of the survey, as compared to an average of only 14 individuals sighted during the first hour in the previous three surveys. Forty-three of these individuals were in one mixed flock of swallows using snags, short trees, and logs on the revetment as brlef roosting spots while feeding over the river.

Nonetheless, it is still possible that events such as this are not highly unusual and the negative correlation between background vegetation and individuals per census is meaningful. A portion of total bird use of revetments does come from birds using the revetment 
as a brief roosting spot. One could argue, then, that flocks of birds searching for a brief roosting spot would fail to land on a revetment, if taller roosting spots were visible immediately adjacent to the revetment. Conversely, even though all the trees and shrubs present on a revetment are under $2 \mathrm{~m}$ in height, they may still be used as roosts if they are the only trees available along a substantial length of stream bank.

It is important to remember that a measure such as individuals per census does not distinguish between visiting birds and resident birds; the two are counted equally. The lack of any significant correlation between adjacent vegetation and measures of breeding bird use suggests that adjacent vegetation most greatly affects the number of visiting individuals.

COMPARISON WITH WOODLAND BIRD SPECIES

ALONG THE COLUMBIA RIVER

In order to assess further the possible importance of revetments as habitat for birds, data from this study were compared with data collected by the OCWRU (1976) in their study of riparian habitats along the Columbia River. Although the methods used by the OCWRU were different from those in this study, a comparison of bird species observed during both studies in spring and summer is instructive.

The bird species sighted at six riparian woodland sites along the Columbia River in spring and summer 1974 and those observed at the eight revetments included in this study during the spring and summer of 1975 are shown in Table VIII. All sites in both studies were visited 


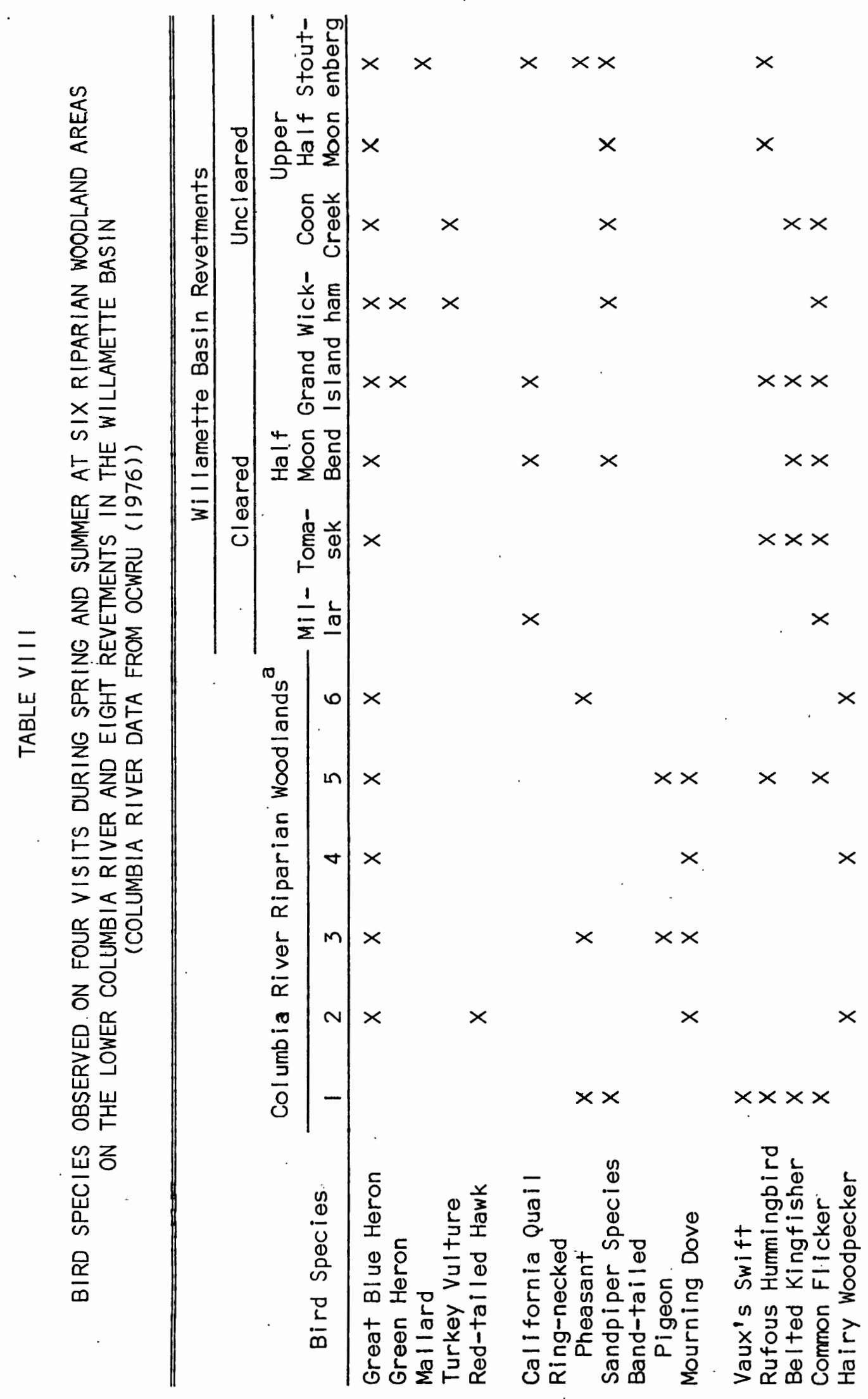




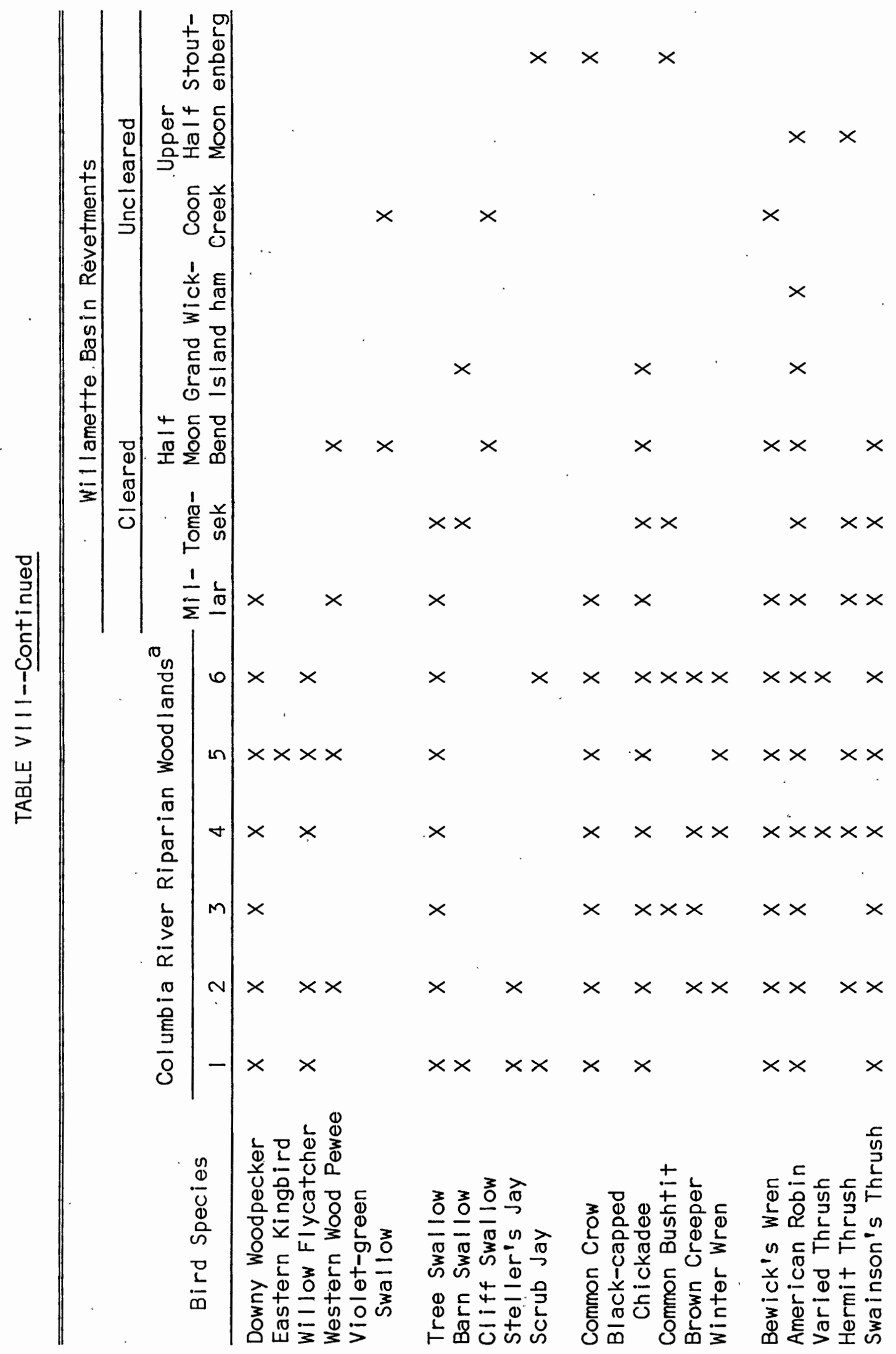




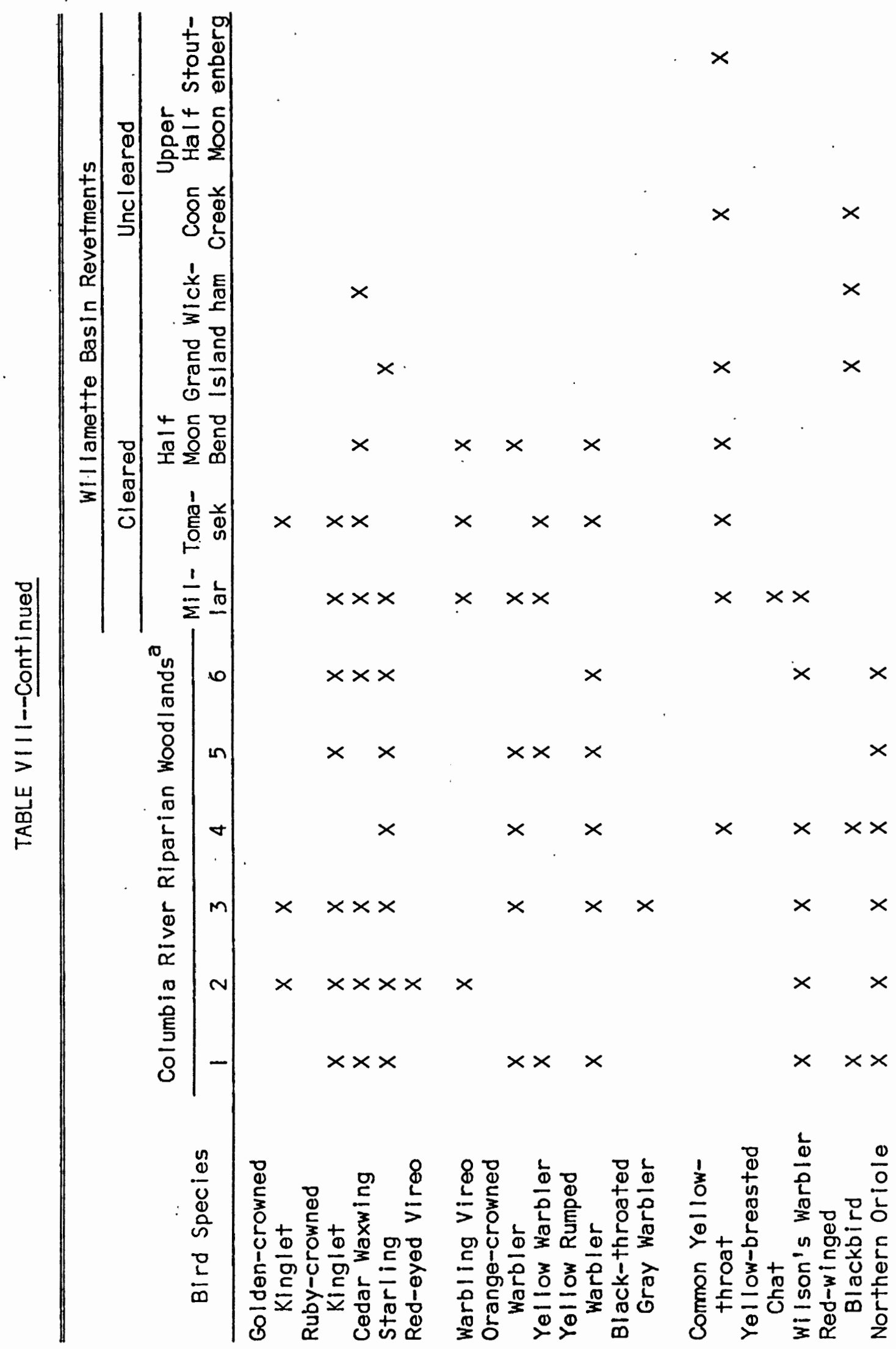




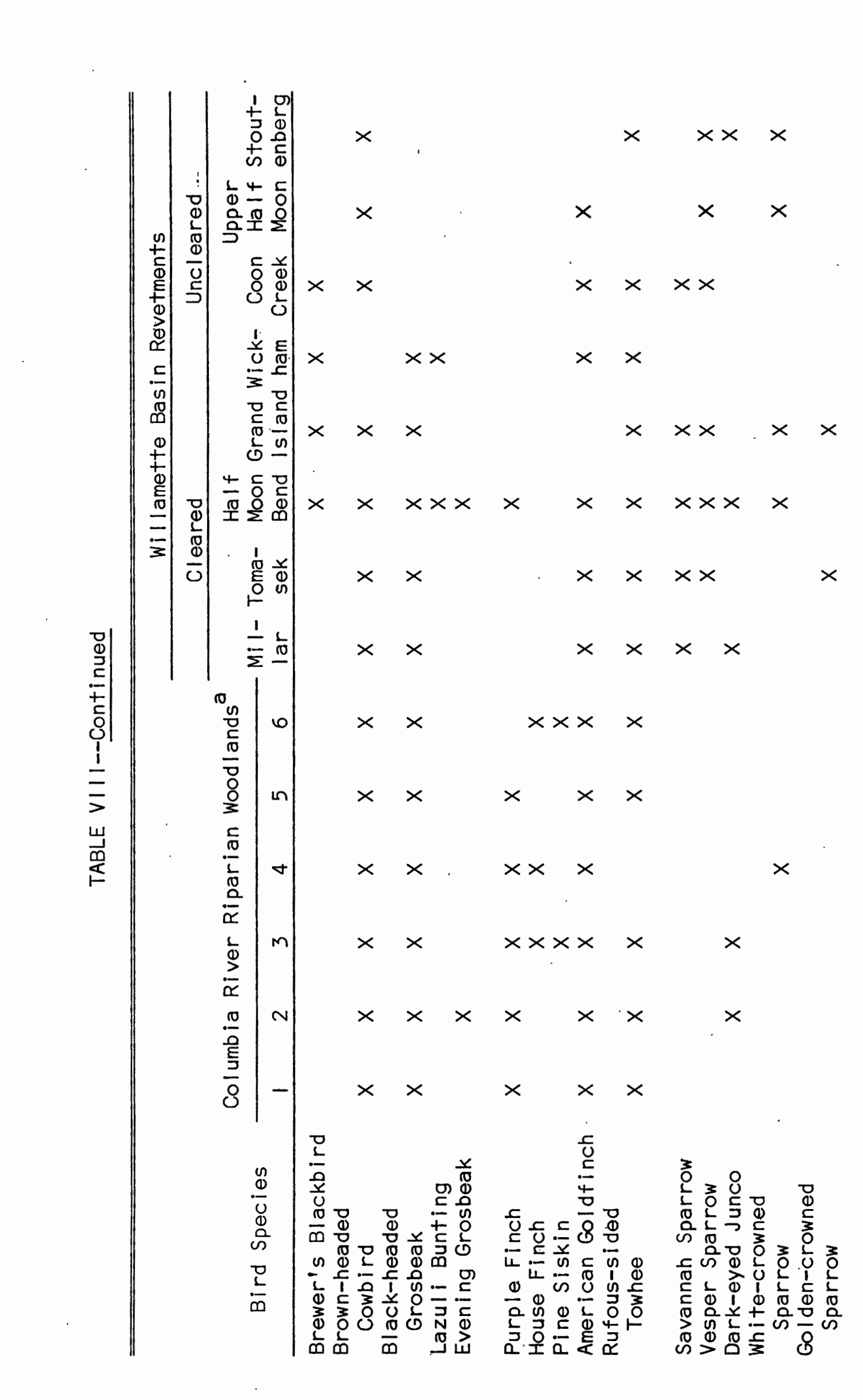




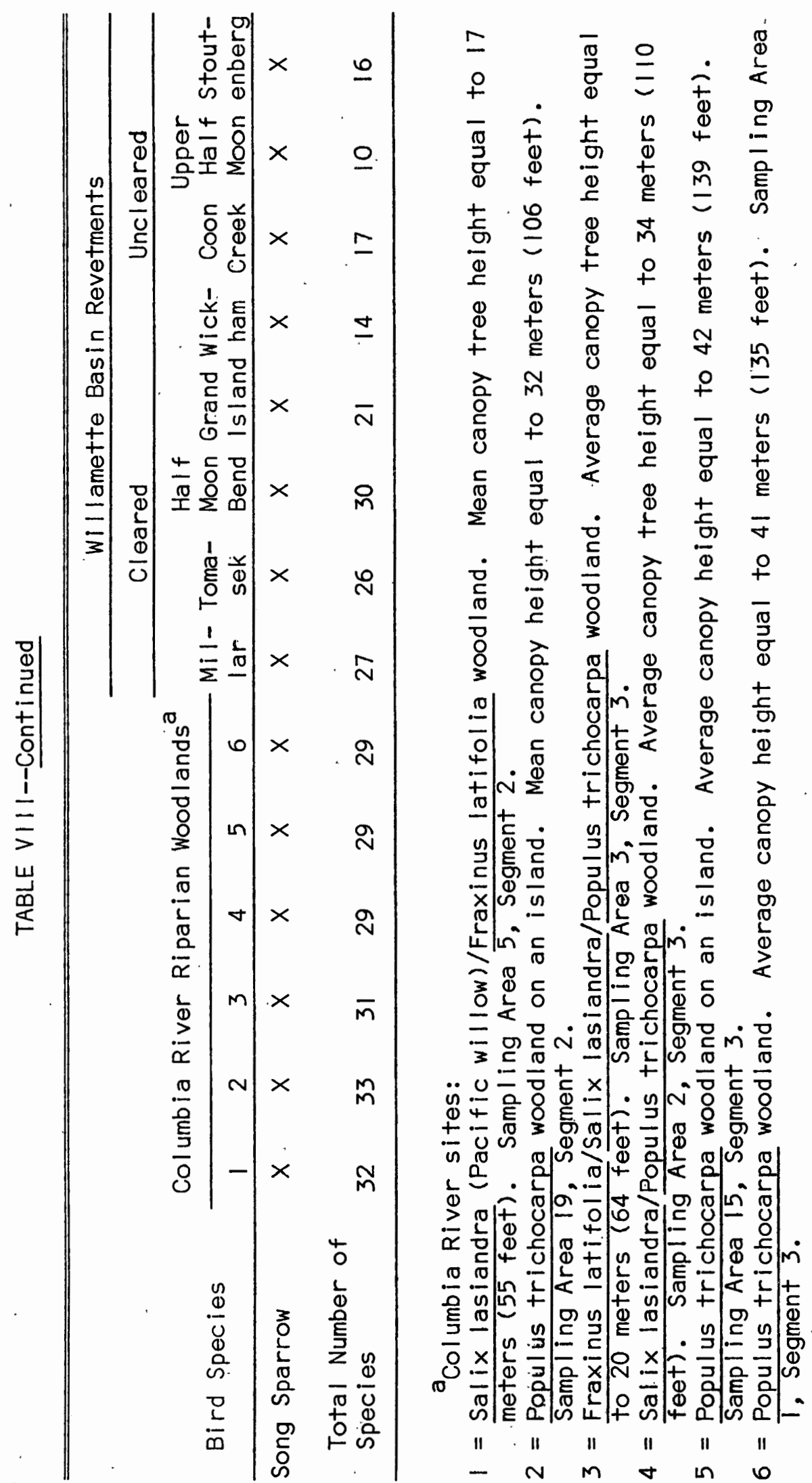


on four different days during the study periods. The six sites along the Columbia River represent all of the riparian woodland sites reported on by the OCWRU that were both west of the crest of the Cascades and not under at least two feet of water during the spring and summer.

Examination of the table reveals several trends. Many of the species. found at all or nearly all of the Columbia River sites were also found at all or nearly all of the uncleared revetments (e.g., black-capped chickadee, black-headed grosbeak, Swainson's thrush). Most species found commonly on Columbia River sites that were not found on revetments are usually tree-associated species (e.g., northern oriole, willow flycatcher, brown creeper). Several species (e.g., common crow, Bewick's wren, Wilson's warbler) were found on most or all Columbia River sites, yet only on Millar, or Millar and one other revetment in this study.

Conversely, species found on most uncleared revetments, but which were uncommon on Columbia River sites, tended to be species associated with low vegetation or the edges of forests (e.g., California quail, common yellowthroat, vesper sparrow). The woodpeckers observed along the Columbia and Willamette are a case in point. The three species sighted were the common flicker, hairy woodpecker, and downy woodpecker. Of these, only the common flicker is an edge species characterized by extensive ground feeding behavior. Examination of the data reveals that the hairy and downy woodpeckers found commonly in riparian forests along the Columbia are replaced by common flickers on revetments along the Wi l lamette. 
Using information in Table VIII, the bird communities can be compared quantitatively using an index of community (Brower and Zar 1977). In this study, the Sorenson coefficient (or "quotient of similarity") has been employed, although the Jaccord coefficient will give results than can be compared in a similar fashion (Brower and Zar 1977). The formula for the Sorenson coefficient $\left(\mathrm{CC}_{s}\right)$ is as follows:

$$
C c_{s}=\frac{2 c}{s_{1}+s_{2}}
$$

where $s_{1}$ and $s_{2}$ are the numbers of species in communities 1 and 2, respectively, and $c$ is the number of species held in common by both communities.

The six Columbia River sites were first compared pair-wise and the resulting coefficients were used to compute an average quotient of similarity between the riparian woodland sites. Each revetment was then compared pair-wise with the Columbia River sites and an average quotient of similarity to riparian woodlands was calculated. The results are shown in Table IX.

\section{TABLE IX}

AVERAGE QUOTIENTS OF SIMILARITY.RESULTING WHEN BIRD SPECIES FOUND AT EACH OF SIX RIPARIAN WOODLANDS ARE COMPARED

PAIR-WISE WITH EACH OTHER AS WELL AS WITH BIRD SPECIES FOUND AT EIGHT REVETMENTS (EXPRESSED IN PERCENT AND PLACED IN DESCENDING ORDER)

\begin{tabular}{|c|c|c|c|c|c|c|c|c|}
\hline \multicolumn{9}{|c|}{ Quotients of Similarity } \\
\hline $\begin{array}{c}\text { Each } \\
\text { Other. }\end{array}$ & Millar & Tomasek & $\begin{array}{l}\text { Half } \\
\text { Moon } \\
\text { Bend } \\
\end{array}$ & $\begin{array}{l}\text { Grand } \\
\text { Island }\end{array}$ & Wickham & $\begin{array}{l}\text { Upper } \\
\text { Half } \\
\text { Moon }\end{array}$ & $\begin{array}{l}\text { Stout- } \\
\text { enberg }\end{array}$ & $\begin{array}{r}\text { Coon } \\
\text { Creek } \\
\end{array}$ \\
\hline 70.0 & 62.6 & 52.4 & 48.4 & 36.3 & 32.2 & 29.7 & 29.4 & 28.8 \\
\hline
\end{tabular}


What is of special interest is that the similarity of the revetments to riparian woodland sites seems to parallel the development of more extensive layers of vegetation. In fact, when the sums of all cover classes over $2 \mathrm{~m}$ in helght for each revetment are regressed against the quotients of similarity, a correlation coefficient of .968 l results. (significant at the .01 level). The least squares line is shown in Figure 4. Examination of the scatter diagram suggests that the relationship may be non-linear. Perhaps similarity to riparian habitats asymptotically approaches a maximum equal to the average similarity between the six riparian sites themselves (70.0). The other independent variables previously employed were also regressed against the quotients of similarity, but all were found to be less than .9681 (see Appendix). The only correlation found to not be significant was that calculated using the measure of background vegetation as the independent variable $(-.4496)$.

The results strongly indicate that, if not maintained by clearing, revetments can in time become suitable habitats for many riparian woodland bird species. Millar, in terms of species observed, approaches the similarity found between the riparian woodland sites themselves (62.6 percent versus 70.0 percent).

Comparisons between riparian woodlands along the Columbia River and revetments along the Willamette River are also useful in explaining the data from Half Moon Bend. The greatest number of bird species, both overall and breeding, were found at Half Moon Bend in apparent contradiction to many findings that the number of species increases with increasing layers of vegetation (reviewed by Balda 1975). 


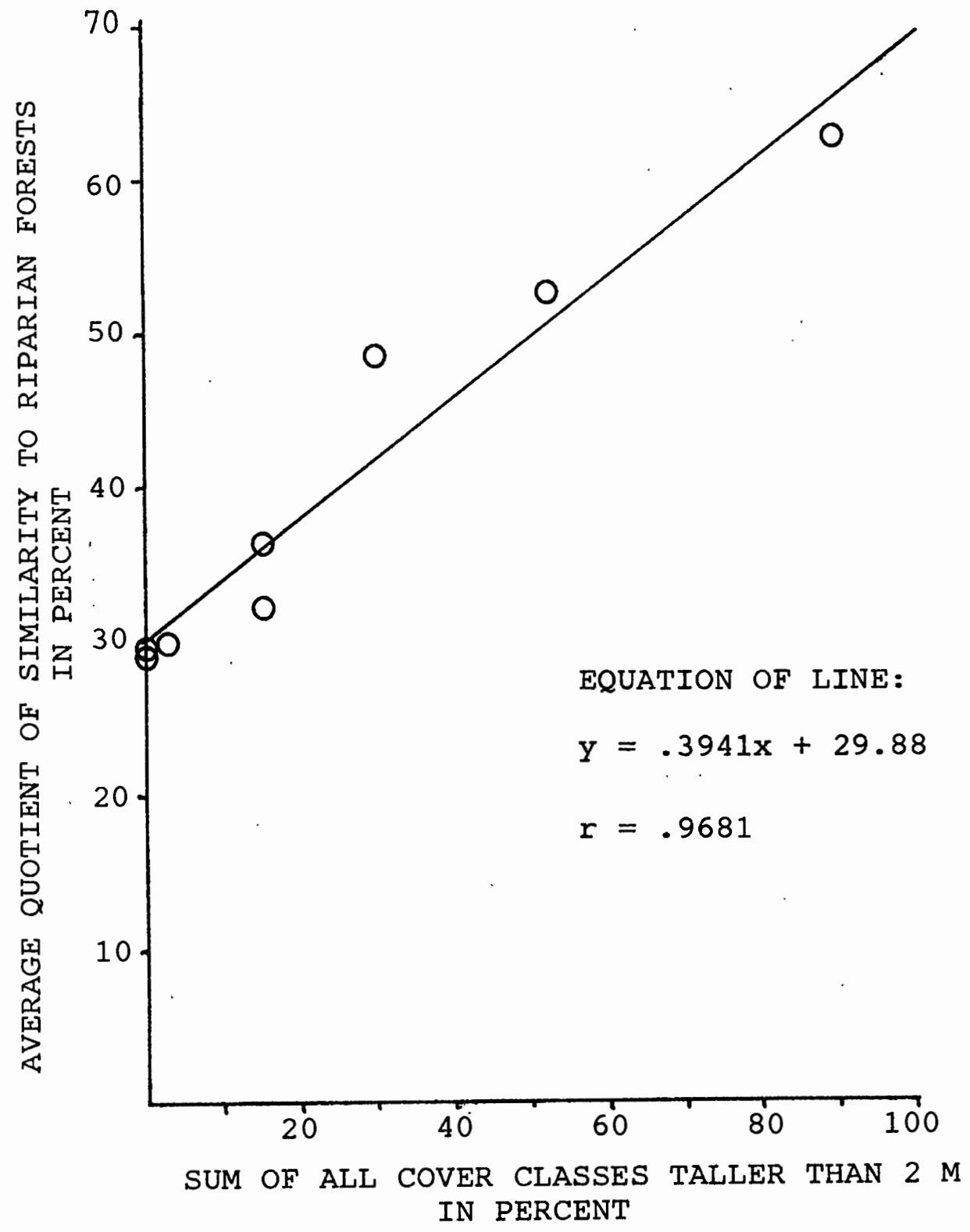

Figure 4. Bird species similarity to riparian woodland regressed against canopy cover of trees greater than 2 meters. 
The results at Half Moon Bend may be partially explained by the screening effect of vegetation: the number of birds using a revetment may actually increase with increased density of foliage, but their detectability decreases. Sandpipers, which feed largely at the water's edge, are a case in point. From the apron, where bird surveys were largely conducted, sandpipers couid easily go undetected at densely vegetated revetments such as Tomasek and Millar.

Another explanation is offered by the distribution of vegetation at Half Moon Bend. It was previously noted that Half Moon Bend was the most heterogeneous of all the revetments studied (see "Methods"). A positive correlation between an increase in bird species and an increase in vegetational layers can only be reasonably expected at homogeneous study sites (MacArthur 1964). I suggest that the greater patchiness of the vegetation at $\mathrm{Hal} f$ Moon Bend resulted in use of the revetment both by species associated with riparian woodlands and species associated with more open areas. A comparison of Tomasek and Half Moon Bend is instructive in this regard. Tomasek has a high density of trees uniformly distributed along nearly its entire length. On Half Moon Bend, although there is a lower number of trees, they are clumped in their distribution and are found largely at the upstream end of the revetment. When the bird species sighted at the two revetments are compared with those sighted at the Columbia River riparian woodland sites, both Tomasek and Half Moon Bend average 14.7 species in common with the riparian woodlands. When compared with the four cleared revetments, Tomasek averages only 8.5 species in common with the cleared sites, while Half Moon Bend averages 11.0 species. The results suggest that 
the groups of trees at Half Moon Bend are large enough and dense enough to attract woodland bird species, while the areas without trees are large enough to attract other species as well.

\section{CONCLUSIONS}

Revetments in the Willamette Valley are used by a significant number of birds in the spring and summer. As vegetation develops on the revetments, more species associated with trees are observed using revetments.

If not maintained by periodic vegetation removal, revetments may provide habitat simultaneously for both bird species associated with herbs and low shrubs and bird specles associated with a dense, forest canopy. In typical forest succession, an increasingly dense canopy correlates with a decreased herb and shrub layer. The reduction in herbs and shrubs is usually attributed to the decrease in the amount of light reaching the forest floor, although other factors could be involved (Krebs 1972). However, Millar has both a dense overstory and a well-developed low-shrub layer, suggesting that an inverse relationship between canopy density and herb-low-shrub density may not hold on revetments. The short dimensions and oblong shape of revetments allows sunlight to reach the surface of the revetment during much of the day even when a dense canopy has developed over the revetment.

The increasing similarity of bird species on revetments to those on riparian woodlands correlated with increasing height and layering of vegetation, demonstrates the potential of revetments as riparian habitat. Riparian habitats have been shown to be some of the richest 
avifaunally in North America (Bottorff 1974; OCWRU 1976; Carothers et al. 1974; Udvardy 1957).. Further, the rapid and continuing disappearance of riparian woodland in the Willamette Valley is well documented (Towle 1974).

Nonetheless, it is expected that revetments cannot serve to actually replace the riparian forests, because, as habitat, revetments appear to be most important for edge species. As Balda (1975) has pointed out, many species attracted to edges have broad ranges of tolerance, good powers of dispersal, and high reproductive rates. Such species are usually in no immediate danger from habitat destruction. Nonetheless, birds found on revetments are still important components of the valley avifauna. It is worth repeating that, in this study, the birds found associated with uncleared revetments include many insectivorous species as well as California quail, a game bird.

It is worthwhile to speculate as to the potential of revetments as nesting sites for two resident specles of present concern in the Willamette Valley--great blue herons and osprey. Both species require large trees near water for nesting. Many trees at Millar are large enough to be used as nesting sites. However, great blue herons are colonial. nesters and both great blue herons and osprey may not tolerate extensive man-caused disturbances around the nesting site. Their large perimeter relative to area could make revetments unsuitable as nesting sites for these two species.

Finally, the evidence presented in this study, although not conclusive, is sufficient to warrant cessation of present revetment maintenance practices. The removal of woody vëgetation has been strongly 
implicated as the primary factor causing significantly reduced bird use of cleared revetments. The significant differences between cleared and uncleared revetments should be considered minimum differences; the actual differences are probably greater. Further, to my knowledge, there is no concrete evidence supporting the idea that trees and blackberry vines weaken revetments.

\section{RESEARCH RECOMMENDATIONS}

From a management point of view, the most pressing need is for research on the actual effects of woody growth and blackberry vines on the stability and strength of revetments. One possible experimental design would involve randomly designating half the revetments in the Willamette Basin to no longer be maintained. After a number of years, any costs of repair to these revetments could then be compared to the cost of maintenance of the control locations.

Alternatives to aerial inspection of revetments should be investigated. One possible alternative would be inspection by boat utilizing lower-paid personnel. Another alternative would be to require sponsors or landowners personally to inspect the revetments for which they are responsible, perhaps once annually in May, and report to the Corps of Engineers any damage to the revetments.

Further research intended to assess the importance of revetments to birds in the Willamette Basin should involve several improvements over the work done in this study. If possible, additional studies should cover a minimum of one full year to reflect seasonal changes. The interval between surveys should be short enough to detect major 
changes during bird migration periods and other short-term fluctuations. In California, Hehnke (unpub.) found that the ratio of number of birds on vegetated berms to the number on riprapped berms varied between a low of 1.3:1 on one day to $56: 1$ on another day in a different season. Information is needed on the habitat needs of migrating birds. Sprunt (1975) has suggested that riparian forests can be of extreme importance to migrant birds, since river valleys are frequently used as migration routes. In his review of studies of migrating birds, however, he found that in not one title or single paper was the question of habitat or habitat management treated directiy.

Balda (1975) has pointed out that even a one-year study may be too short. He found that breeding densities between years varied as much as 80 percent for some species in Pinus ponderosa forests that had not been physically altered between breeding seasons.

A method should be devised for censusing birds on revetments that is comparable to methods used in other studies. The method would have to take into account the unusual shape of revetments and allow for changes in water level. Birds commonly found along the water's edge (e.g., sandpipers) could be censused from the opposite bank so that the screening effect of vegetation on the revetment would be avoided. The recording of data on bird use should be of such detail and uniformity as to be able to separate breeding, feeding, roosting, and other uses of revetments by birds.

In conjunction with the bird census, more measurements of vegetational and physiognomic diversity both on and adjacent to revetments are needed. Aithough its biological importance has recently been 
questioned (Willson 1974), measurement of foliage height diversity (MacArthur and MacArthur 1961) seems necessary in order to make comparisons with other studies. It has been suggested (Karr 1968) that available water may serve as a partial layer of foliage that needs to be taken into account in some way.

To study the various environmental factors affecting such a small area as a revetment, a large number of revetments could be used. This would allow a comparison of the relative importance of various factors, such as vegetation bordering and vegetation actually on revetments through multiple regression analysis.

To determine more precisely the effects of clearing on bird use, a before-and-after study could be employed. The effects of areas bordering the revetment could then be held reasonably constant. Yearly changes in the local bird populations could be monitored by the use of a suitable "control" site that would be studied along with the revetment being cleared. After making allowances for such yearly fluctuations in bird populations, differences in bird use before and after clearing could be reasonablyattributed to the effects of clearing. 
REFERENCES CITED 


\section{REFERENCES CITED}

American Ornithologists' Union (AOU). 1957. Check-List of North American Birds. Fifth ed. AOU, Baltimore.

American Ornithologists' Union. 1973. Thirty-Second Supplement to the AOU Check-List of North American Birds. Auk 90:411-419.

Balda, R. P. 1975. Vegetation Structure and Breeding Bird Diversity. In Proc. of the Symp. on Management of Forest and Range Habitats for Nongame Birds, Tucson, Arizona, 6-9 May 1975. USDA Forest Service. Gen. Tech. Report WO-I.

Benton, A. H. and W. E. Werner, Jr. 1972. Manual of Field Biology and Ecology. Fifth ed. Burgess Publ. Co., Minneapolis, Minn. $400 \mathrm{pp}$.

Bottorff, R. L. 1974. Cottonwood Habitat for Birds in Colorado. Amer. Birds 28:975-979.

Brower, J. E. and J. H. Zar. 1977. Field and Laboratory Methods for General Ecology. Wm. C. Brown Co., Dubuque, lowa. Page 143.

Carothers, S. W., R. R. Johnson and S. W. Aitchison. 1974. Population Structure and Social Organization of Southwestern Riparian Birds. E. M. Banks and M. F. Willson (eds.). Ecology and Evolution of Social Organization. Amer. Zool. 14:97-108.

Daubenmire, R. F. 1959. Canopy Coverage Method of Vegetation Analysis. NW SCi. 33:43-64.

Emlen, J. T. 1971. Population Densities of Birds Derived from Transect Counts. Auk $88: 323-342$

Forbes, R. B., P. J. Paquet, C. B. Perry and R. Willis. 1976. Revetment Clearing: Its Influence on Riparian. Wildlife Communities. Final report submitted to the U. S. Army Engineer District, Portland, Oregon (xerox copy).

Hitchcock, C. L. and A. Cronquist. 1973. Flora of the Pacific Northwest. Univ. of Washington Press, Seaftle, Washington. $730 \mathrm{pp}$.

International Business Machines (IBM). 1957. The 1130 Scientific Subroutine Package. IBM Publ. II30-CM-02X. IBM Technical Publications Dept., White Plains, N.Y. Page 150. 
On Stripmined Land in East-central Illinois. Condor 70:348-357.

Kendeigh, S. C. 1944. Measurement of Bird Populations. Ecol. Monogr. 14:67-106.

Krebs, C. J. 1972. Ecology: The Experimental Analysis of Distribution and Abundance. Harper and Row, Inc., New York. Page 88.

MacArthur, R. H. 1964. Environmental Factors Affecting Bird Species Diversity. Am. Natural ist 98:387-397.

MacArthur, R. H. and J. W. MacArthur. 1961. On Bird Species Diversity. Ecology 42:594-598.

Odom, E. 1971. Fundamentals of Ecology. W. B. Saunders Co., Phila-

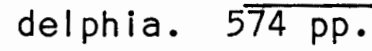

Oregon Cooperative Wildlife Research Unit (OCWRU). 1976. Draft of final report: Inventory of Riparian Habitats and Associated Wildlife along the Columbia River. Ore. St. Univ., Corvallis, Oregon. (Prepared for U. S. Army Corps of Engineers Wildlife Work Group.)

Roscoe, J. T. 1975. Fundamental Research Statistics for the Behavioral Sciences. Second ed. Holt, Rinehart and Winston, Inc., New York. 483 pp.

Sprunt, A. 1975. Habitat Management Implications of Migration. In Proc. of the Symp. On Management of Forest and Range Habitats for Nongame Birds, Tucson, Arizona, 6-9 May 1975. USDA Forest Service. Gen. Tech. Report WO-1.

Towle, J. C. 1974. Woodland in the Willamette Valley: An Historical Geography. Unpub. doctoral dissertation. Univ. of Oregon, Eugene, Oregon.

Udvardy, M. D. F. 1957. An Evaluation of Quantitative Studies in Birds. Cold Spring Harbor Symp. Quant. Biol. 22:301-311.

U. S. Army Engineer District, Portland, Oregon (USAEDPO). 1975. Final Environmental Statement: Corps of Engineers Actions Affecting Riverbanks and Channels in Willamette River Basin, Oregon. USAEDPO, Portland, Oregon.

Willson, M. F. 1974. Avian Community Organization and Habitat Structure. Ecology 55:1017-1029. 
APPENDIX 


\section{APPENDIX}

\section{LITERATURE REVIEW}

\section{Historical}

Towle (1974), in his historical study of woodlands in the Willamette Valley, states, "In 1854, the floodplains of the Willamette and the Santiam had supported a continuous forest cover that ranged from about one mile to five miles in width." By 1936, appreciable tracts of this floodplain, or gallery, forest had been cleared and the land converted to agricultural use. After 1936 the clearing accelerated until,

The gallery forest had, by 1970 , been reduced to a narrow, discontinuous ribbon of woodland immediately along the willamette and its major tributaries, and small, isolated forest remnants scattered across the floodplain. . . The lowland forests are mostly gone.

Towle attributes the intensified clearance of the floodplain forest to two major factors: (1) a comprehensive flood control program, and (2) the expansion of irrigation. Both of these factors made the floodplain land more attractive for agricultural use. Most of the land that had once been floodplain forest is today irrigated farmland.

The comprehensive flood control program in the Willamette Valley began in 1936 with Congressional passage of a Flood Control Act. Although the 1936 and subsequent flood control acts affecting the Willamette River Basin have largely emphasized reservoirs, the acts also authorized the construction of bank protection works, including rock revetments. Details of the history of bank protection in the Willamette 
Valley may be obtained from the U.S. Army Engineer District, Portland, Oregon (1975).

\section{Environmental Setting}

Franklin and Dyrness (1973) list the Willamette as one of the 15 physiognomic provinces of Oregon and Washington. They describe the valley as

- . a broad structural depression oriented North-South and situated in Oregon between the Coast Ranges on the west and the Cascade Range on the east. . . The valley floor has a very gentle northfacing slope... As a result, Willamette River is a sluggish stream with many meanders...

The climate of the Willamette Valley has been described as maritime and remarkably homogeneous (W. G. Loy et al. 1976) Weather data from four locations in the Willamette Valley are listed in Table 1. Additional climatic details, as well as information on the geology and soil. of the Willamette Valley, are given by Franklin and Dyrness (1973).

Riparian Vegetation

The riparian communities of the Willamette Valley are also described by. Franklin and Dyrness (1973). The authors state that these communities have not been well studied. According to Franklin and Dyrness, Populus trichocarpa (black cottonwood) is a characteristic dominant tree species. Other tree species usually associated with riparian forests include Salix sp. (willows) and Fraxinus latifolia (Oregon ash). In many areas, Acer macrophyllum (big-leaf maple), Quercus garryana (Oregon white oak) and Alnus rubra (red alder) are also constituents of riparian forests in the Willamette Valley. 


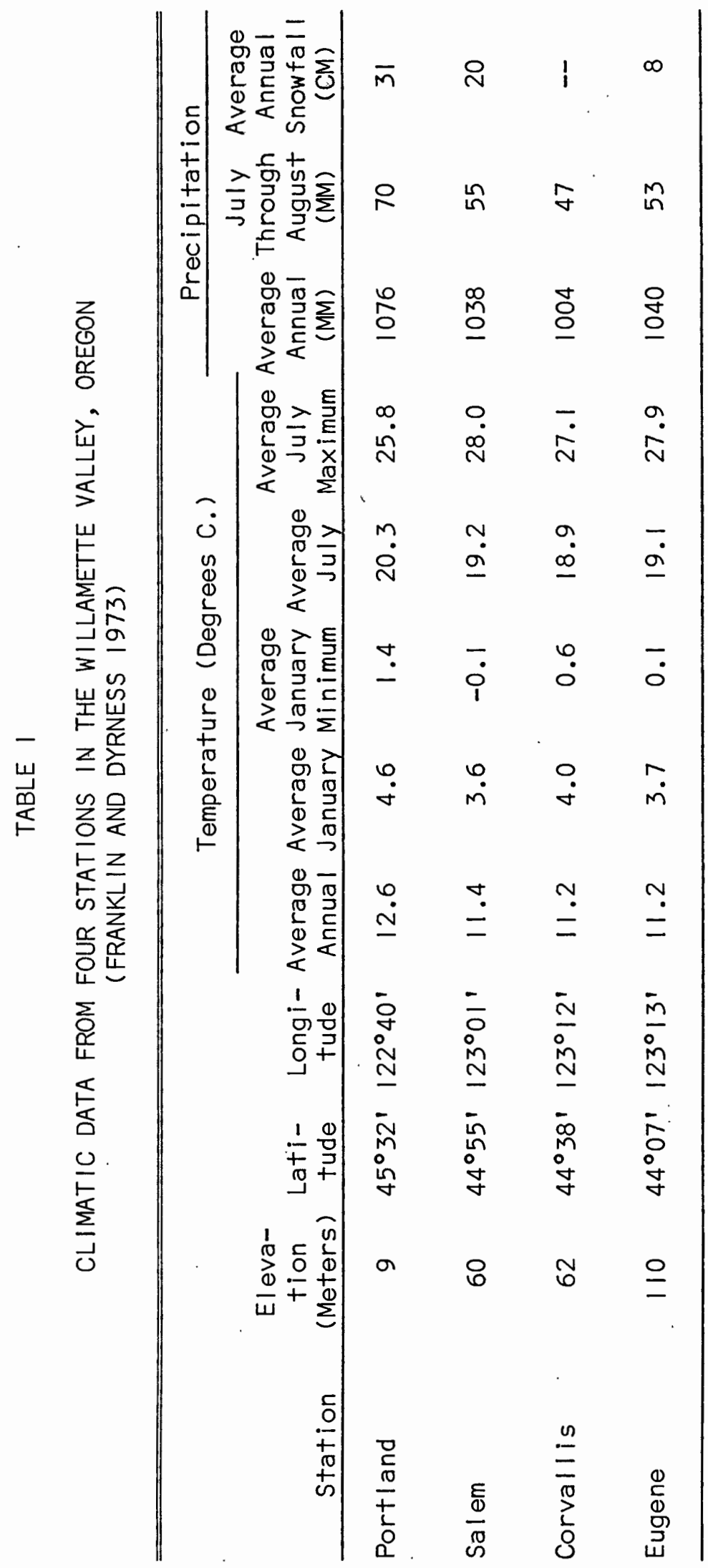


The OCWRU (1976) recently completed an inventory of riparian habitats and associated wildlife along the lower Columbia River. Eightytwo habitats were described in terms of cover, density, and size of plants. The vegetative composition of several Populus trichocarpa stands occurring in western Oregon (both pure and mixed with other species) is described, as are several areas of riprapped shoreline. However, all of the riprapped sites are located east of the crest of the Cascades and were nearly barren of vegetation; therefore, they are not of particular interest here.

In summary, the riparian vegetation in Oregon has only recently begun to be studied intensively. No studies of riparian vegetation on revetments were found.

Riparian Avifauna

There is much data showing the richness of the avifauna in riparian habitats. Udvardy (1957) reviewed 20 years of breeding bird census data collected by the National Audubon Society beginning in 1936. Most of these censuses came from the east central United States. In homogeneous habitats in the United States, the highest densities of breeding pairs occurred in twenty censuses undertaken in mixed bottomland and floodplain forests.

In a review of Audubon breeding bird censuses in Colorado, Bottorff (1974) examined the importance of riparian Populus groves. He found Populus habitat to have breeding bird densities well in excess of all other natural habitats in Colorado. Bottorffalso reviewed additional studies in Colorado showing very high bird use of Populus 
habitats. He concluded that Populus habitat in Colorado is relatively scarce, but very important for bird use.

The importance of riparian habitat to birds in the arid southwest has been well documented. Carothers and Johnson (1975) reviewed the available information from that area. Data from homogeneous Populus fremontii stands along the Verde River in Arizona (Carothers et al. 1974) led the authors to conclude that there is no other habitat type in North America that is as important to as large an aggregation of non-colonial nesting bird species.

Hehnke (unpub.) collected data on bird use of berms along the Sacramento River in California. He found much higher bird use on heavily vegetated berms having a significant tree overstory than on riprapped berms having only herbs and shrubs. He concluded that the riparian vegetation studied is extremely important to avian populations on the berms themselves, but it has an even more pronounced influence on wildilfe populations on adjacent agricultural lands. Hehnke's final report will also review several additional studies done in California indicating the importance of riparian vegetation to wildlife.

In the OCWRU (1976) study, stands of Populus trichocarpa, both pure and mixed with other species, have been singled out as representing unique habitat, rich in both numbers and species of birds. The authors state that the riparian habitats studied had the highest densities ever recorded for bird communities. It should be noted, however, that their techniques involved counting all birds, while most studies have been limited to breeding birds only. 
At this point it seems reasonable to ask why riparian habitats are so productive with respect to avifauna. A main reason given by many authors (Bottorff 1974; Hehnke unpub.; OCWRU 1976) is the so-called "edge effect." According to Odum (1971), the term "edge effect" is used when referring to conditions found at an ecotone. He defines an ecotone as a transition between two or more diverse communities. When the number of species and the population density of some of the species are greater in the ecotone itself, relative to the bordering communities, the tendency for increased variety and density is termed the edge effect. Most riparian woodlands studied are relatively small and I inear in form. The large perimeter, or edge, relative to area provides for a significant edge effect. Therefore, in a riparian woodland we would expect to find not only forest-type birds, but also the "edge species." Edge species, according to Odum (1971), require as part of their habitat, or life history, two or more adjacent communities that differ greatly in structure. A familiar example of an edge species is the American robin, which requires trees for nest sites, yet feeds largely on the ground in open areas.

The fact that riparian vegetation is frequently tall and multilayered has also been used to help explain the richness of riparian habitat (Hehnke unpub.; OCWRU 1976). Increases in vegetational layers have been found to correlate often with increases in both numbers and species of birds present (MacArthur 1964).

River bottoms are rich in nutrients and are therefore highly productive. The OCWRU Report (1976) suggested that this provides more 
food for birds and perhaps the dense vegetation provides hiding places from predators and neighbors.

Carothers et al. (1974) found that in Arizona the layers of vegetation were insufficient to explain the bird species diversity in Populus fremontii stands. The heavily populated stands were bordered by agricultural lands and the Verde River. Only 36 percent of the birds in the cottonwood stand had "class A" territories (i.e., foraged exclusively on their defended territories). Most of the birds spent considerable time harvesting the unutilized standing crop of food on adjacent agricultural lands or over the river. The authors suggested that the size of breeding bird populations in these habitats is regulated by competition for a resource other than food, that is in short supply--probably nest sites.

The OCWRU report suggested that there may be an island effect associated with riparian vegetation, because they are often isolated from physiognomically similar habitat. Birds may be attracted to the visual stimulus of the riparian vegetation in what is otherwise a "visual void."

Revetments

The U.S. Army Engineer District, Portland, Oregon Environmental Impact Statement (1975) covers the history, sponsorship, structural features, repair, maintenance, economic benefits, and economic costs of rock revetments. Informative comments from various agencies and groups are also included. The section on structural features states:

Revetments are typically constructed on the outside of river bends where a meander of the channel has caused the current to be 
directed into the bank. . . Today revetments in the Willamette Basin are constructed of quarried stone dumped on a prepared slope from the bank top, with some hand placement.

Forbes et al. (1976) have apparently completed the first study of revetment vegetation and wildlife conducted in the Willamette Basin. 
References cited

Bottorff, R. L. 1974. Cottonwood Habitat for Birds in Colorado. Amer. Birds 28:975-979.

Carothers, S. W. and R. R. Johnson. 1975. Water Management Practices and Their Effects on Nongame Birds in Range Habitats. In Proc. of the Symp. on Management of Forest and Range Habitats for Nongame Birds, Tucson, Arizona, 6-9 May 1975. USDA Forest Gen. Tech. Report w0-1.

Carothers, S. W., R. R. Johnson and S. W. Aitchison. 1974. Population Structure and Social Organization of Southwestern Riparian Birds. E. M. Banks and M. F. Willson (eds.). Ecology and Evolution of Social Organization. Amer. Zool. 14:97-108

Forbes, R. B., P. J. Paquet, C. B. Perry and R. Willis. 1976. Revetment Clearing: Its Influence on Riparian Wildlife Communities. Final report submitted to the U. S. Army Engineer District, Portland, Oregon (xerox copy).

Franklin, J. F. and C. T. Dyrness. 1973. Natural Vegetation of Oregon and Washington. USDA Forest Service Gen. Tech. Report PNW-8.

Hehnke, M. F. Unpub. Review Draft. A Comparison of Four Riverine Habitat Types and Their Respective Values to Avian Resources. U. S. Fish \& Wildlife Service, Sacramento, California.

Loy, W. G., S. Allan, C. P. Patton and R. D. Plank. 1976. Atlas of Oregon. Univ. of Oregon (publisher), Eugene, Oregon. $215 \mathrm{pp}$.

MacArthur, R. H. 1964. Environmental Factors Affecting Bird Species Diversity. Am. Naturalist 98:387-397.

Odom, E. 1971. Fundamentals of Ecology. W. B. Saunders Co., Philadelphia. $574 \mathrm{pp}$.

Oregon Cooperative Wildlife Research Unit (OCWRU). 1976. Draft of final report: Inventory of Riparian Habitats and Associated Wildlife along the Columbia River. Ore. St. Univ., Corvallis, Oregon. (Prepared for U. S. Army Corps of Engineers Wildlife Work Group.)

Towle, J. C. 1974. Woodland in the Willamette Valley: An Historical Geography. Unpub. doctoral dissertation. Univ. of Oregon, Eugene, Oregon.

Udvardy, M. D. F. 1957. An Evaluation of Quantitative Studies in Birds. Cold Spring Harbor Symp. Quant. Biol. 22:301-311. 
U. S. Army Engineer District, Portland, Oregon (USAEDPO). 1975. Final Environmental Statement: Corps of Engineers Actions Affecting Riverbanks and Channels in Willamette River Basin, Oregon. USAEDPO, Portland, Oregon. 
ADDITIONAL STUDY SITE INFORMATION

TABLE 2

PLACEMENT OF BIRD SURVEY TRANSECTS ALONG

LENGTH OF REVETMENT

\begin{tabular}{lcc}
\hline & \multicolumn{2}{c}{ Placement of Transecta } \\
\cline { 2 - 3 } Revetment & Upstream End & Downstream End \\
\hline Stoutenberg & $C$ & $E$ \\
Grand Island & $E$ & $E$ \\
Tomasek & $E$ & $E$ \\
Millar & $E$ & $C$ \\
Wickham & $C$ & $C$ \\
Coon Creek & $C$ & $E$ \\
Half Moon Bend & $E$ & $C$ \\
Upper Half Moon Bend & $C$ & $E$ \\
\hline
\end{tabular}

$$
\begin{aligned}
{ }^{a_{C}} & =\text { Revetment length continues beyond end of transect } \\
E & =\text { Revetment ends at end of transect }
\end{aligned}
$$

For example, at Stoutenberg the downstream end of the bird survey transect begins at the downstream end of the revetment. The revetment is longer than the bird survey transect; therefore, the revetment continues beyond the upstream end of the transect. 
Revetment: Stoutenberg

Area: Willamette No. I

Location: River Mile (RM), 65.6 (106 KM)

S. $1 / 2$, S. 10, T. 5 S, \$. $3 \mathrm{w}$

Elevation: Approx. $24 \mathrm{M}$

Total Length:' $1193 \mathrm{M}$

Shore: ${ }^{2}$ Left Bank

Average Aspect of Bird Survey Area: ESE

Date of Construction: 1952

Maintenance History: Cleared summer 1974; sprayed late 1960s

'All total length figures are from Corps of Engineer data converted from feet.

${ }^{2}$ All shore information is relative to an observer heading downstream. 
Revetment: Grand Island

Area: Willamette No. I

Location: RM, 69.1 (1111 KM)

NW I/4, S. 25, T. 5 S, R. 3 W

Elevation: Approx. $26 \mathrm{M}$

Total Length: '

Shore: Left Bank

Average Aspect of Bird Survey Area: SE

Date of Construction: 1938

Maintenance History: Sprayed late 1960s

'Although listed as longer than $700 \mathrm{M}$, only 650 meters could be located. 
Revetment: Tomasek

Area: Santiam

Location: $\operatorname{RM} 4.6(7.4 \mathrm{KM})$

SW 1/4, S. 56, T. 9 S, R. 3 W

Elevation: $55 \mathrm{M}$

Total Length: $657 \mathrm{M}$

Shore: Right Bank

Average Aspect of Bird Survey Area: SSE

Date of Construction: 1955

Maintenance History: Sprayed late 1960s 
Revetment: Millar

Area: Santiam

Location: $\mathrm{RM} 6.2(10 \mathrm{KM})$

NW 1/4, S. 66, T. $10 \mathrm{~S}, \mathrm{R} .3 \mathrm{~W}$

Elevation: $58 \mathrm{M}$

Total Length: $1186 \mathrm{M}$

Shore: Right Bank

Average Aspect of Bird Survey Area: WSW

Date of Construction: 1948

Maintenance History: No maintenance 
Revetment: Wickham

Area: Santiam River

Location: $\mathrm{RM} 8.3(13 \mathrm{KM})$

SE $1 / 4, \mathrm{~S} .66, \mathrm{~T} .10 \mathrm{~S}, \mathrm{R} .3 \mathrm{~W}$

Elevation: $61 \mathrm{M}$

Total Length: $1418 \mathrm{M}$

Shore: Right Bank

Average Aspect of Bird Survey Area: S

Date of Construction: 1950

Maintenance History: Cleared summer 1974; sprayed late 1960s 
Revetment: Coon Creek

Area: Willamette No. 2

Location: RM 123.1 (199 KM)

N 1/2, S. 58, T. II S, R. 4 W

Elevation: $57 \mathrm{M}$

Total Length: $997 \mathrm{M}$

Shore: Right Bank

Average Aspect of Bird Survey Area: NW

Date of Construction: 1962

Maintenance History: Cleared summer 1974; sprayed late 1960s 
Revetment: Half Moon Bend

Area: Willamette No: 2

Location: RM 125.2 (202 KM)

SW $1 / 4$, S. $86, T .11$ S, R. $4 \mathrm{~W}$

Elevation: $58 \mathrm{M}$

Shore: Left Bank

Average Aspect of Bird Survey Area: NE

Date of Construction: 1948

Maintenance History: Sprayed late 1960 s

Total Length: $1627 \mathrm{M}$ 
Revetment: Upper Haif Moon Bend

Area: Willamette No. 2

Location: RM 126.3 (204 KM)

SW 1/4, S. 21, T. II S, R. 4 W

Elevation: $58 \mathrm{M}$

Shore: Right Bank

Average Aspect of Bird Survey Area: S

Date of Construction: 1949

Ma intenance History: Cleared summer 1974; sprayed late 1960s

Total Length: 1593 
ADDITIONAL RESULTS

TABLE 3

CORRELATION COEFFICIENTS: DEPENDENT VARIABLES

REGRESSED PAIR-WISE AGAINST EACH OTHER

\begin{tabular}{|c|c|c|c|c|c|c|c|c|}
\hline & Variable & (2) & (3) & (4) & (5) & $(6)$ & (7) & (8) \\
\hline (1) & $\begin{array}{l}\text { Effect of } \\
\text { Clearing } \\
\text { (Nominal } \\
\text { Variable) }\end{array}$ & .4750 & -.8741 & .8729 & -.7205 & -.6865 & -.8080 & -.6991 \\
\hline (2) & $\begin{array}{l}\text { Adjacent } \\
\text { Vegetation } \\
-- \text { Percent } \\
\text { of Transect } \\
\text { Bordered } \\
\text { by Dense } \\
\text { Natural } \\
\text { Cover }\end{array}$ & & -.4817 & .4952 & -.3411 & -.3243 & -.4787 & -.3766 \\
\hline (3) & $\begin{array}{l}\text { Log of } \\
\text { Density } \\
\text { of Trees }\end{array}$ & & & -.9938 & .8249 & .7714 & .9227 & .8337 \\
\hline (4) & $\begin{array}{l}\text { Rank of } \\
\text { Density } \\
\text { of Trees }\end{array}$ & & & & -.8231 & -.7600 & -.9348 & -.8171 \\
\hline (5.) & $\begin{array}{l}\text { Sum of } \\
\text { All Cover } \\
\text { Classes } \\
>2 \text { Meters }\end{array}$ & & & & & .9910 & .9397 & .9252 \\
\hline (6) & $\begin{array}{l}\text { Sum of All } \\
\text { Woody Cover } \\
\text { Classes }\end{array}$ & & & & & & .9013 & . 9238 \\
\hline (7) & $\begin{array}{l}\text { Sum of All } \\
\text { Woody Cover } \\
\text { Classes be- } \\
\text { tween } 2 \text { and } \\
15 \text { Meters }\end{array}$ & & & & & & & .9129 \\
\hline (8) & $\begin{array}{l}\text { Sum of All } \\
\text { Cover } \\
\text { Classes }\end{array}$ & & & & & & & \\
\hline
\end{tabular}


TABLE 4

CORRELATION COEFFICIENTS BETWEEN BIRD SPECIES SIMILARITY TO

RIPARIAN WOODLANDS AND MEASURES' OF EFFECTS OF CLEARING, TREE DENSITY, CANOPY COVER, AND ADJACENT VEGETATION

\begin{tabular}{lc}
\hline $\begin{array}{c}\text { Average Sorensen Coefficients } \\
\text { Regressed Against }\end{array}$ & $\begin{array}{c}\text { Resulting Correlation } \\
\text { Coefficients }\end{array}$ \\
\hline Effect of Clearing (Nominal Variable) & -.8286 \\
Log of Density of Trees (Base 10) & .8735 \\
Rank of Density of Trees. & -.8837 \\
Sum of All Cover Classes & .9224 \\
Sum of All Woody Cover Classes & .9441 \\
Sum of AlI Woody Cover Classes Greater Than & .9681 \\
2 M & \\
Sum of All Woody Cover Classes between 2 M \\
and I5 M
\end{tabular}




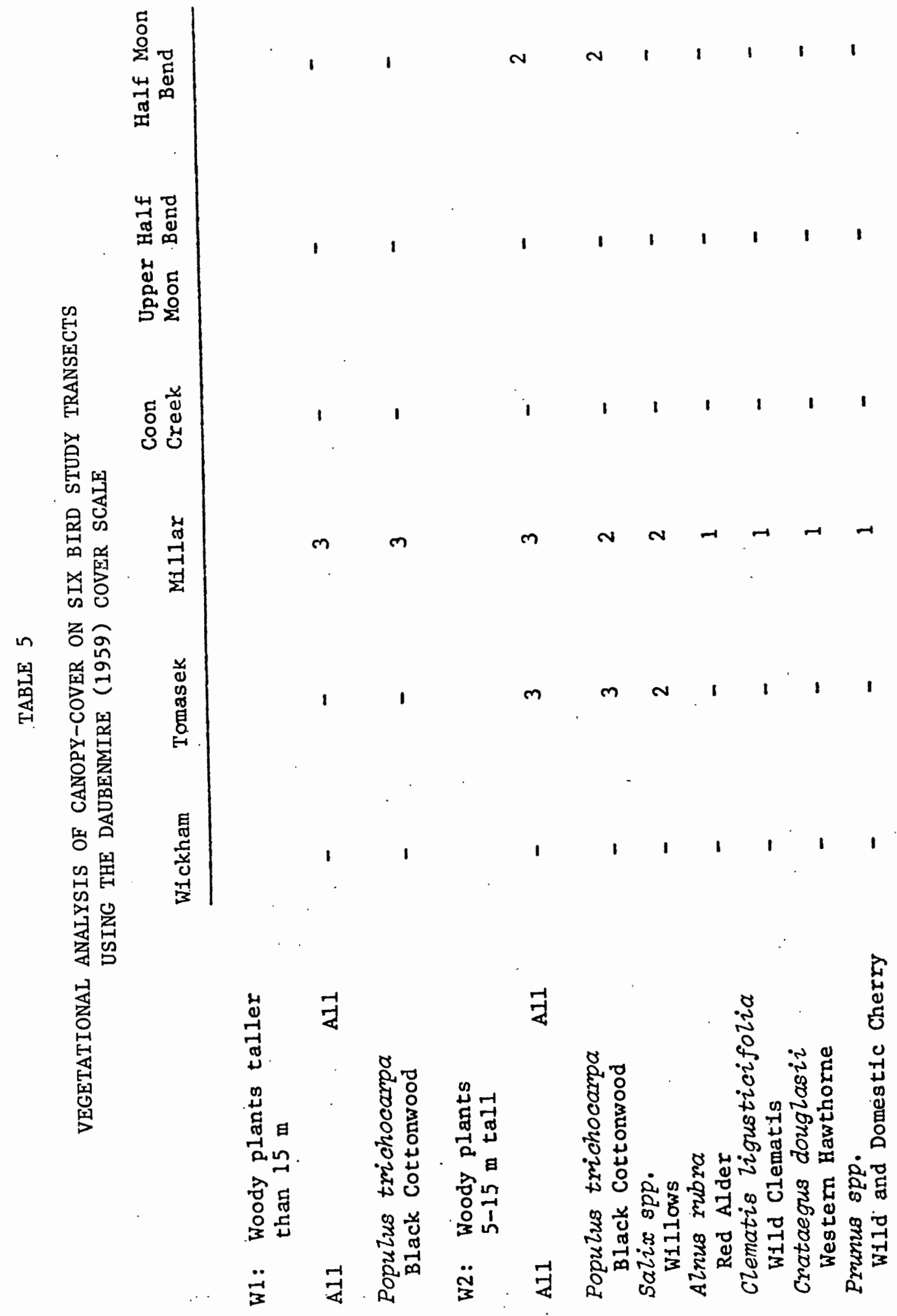




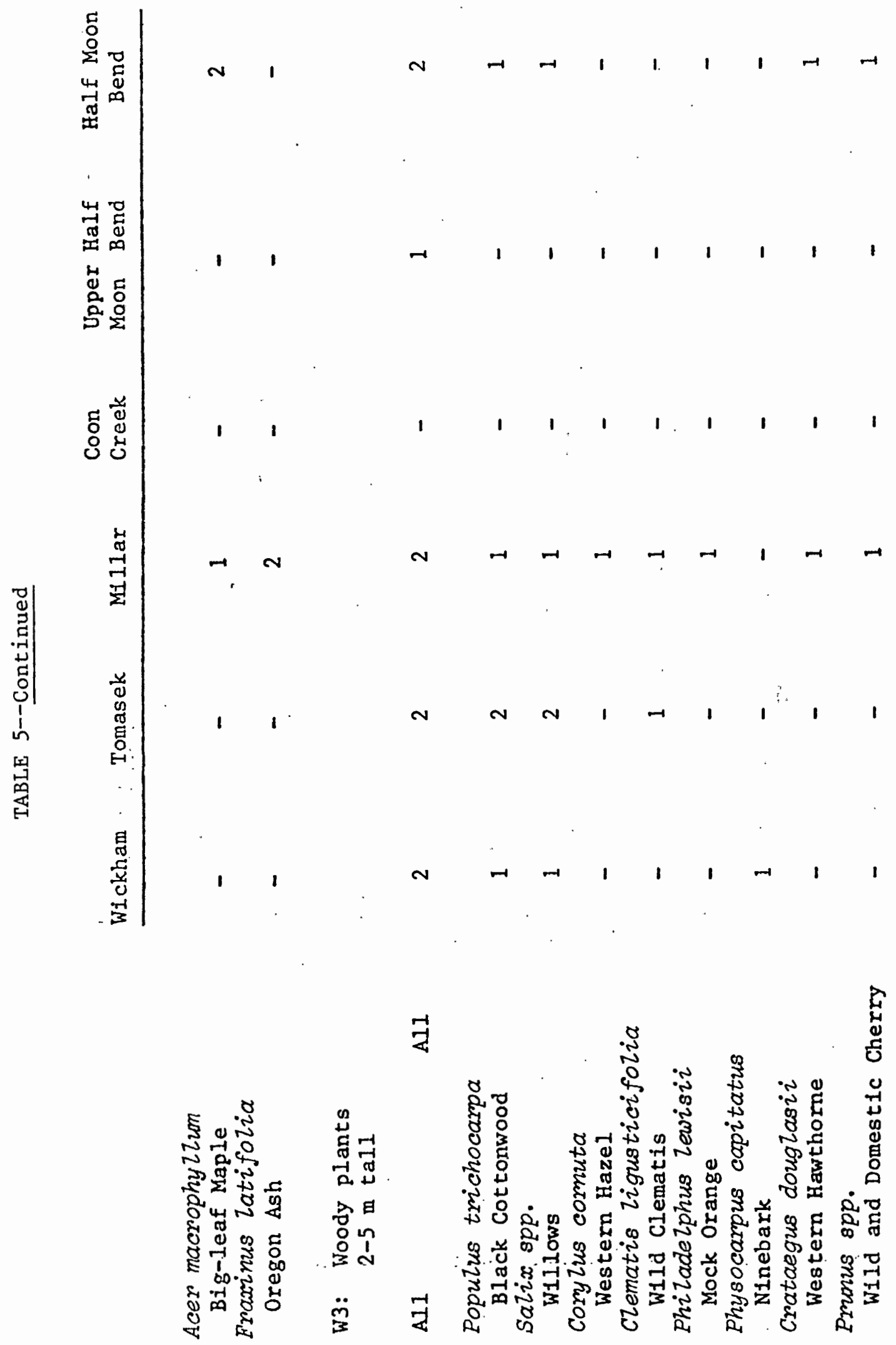




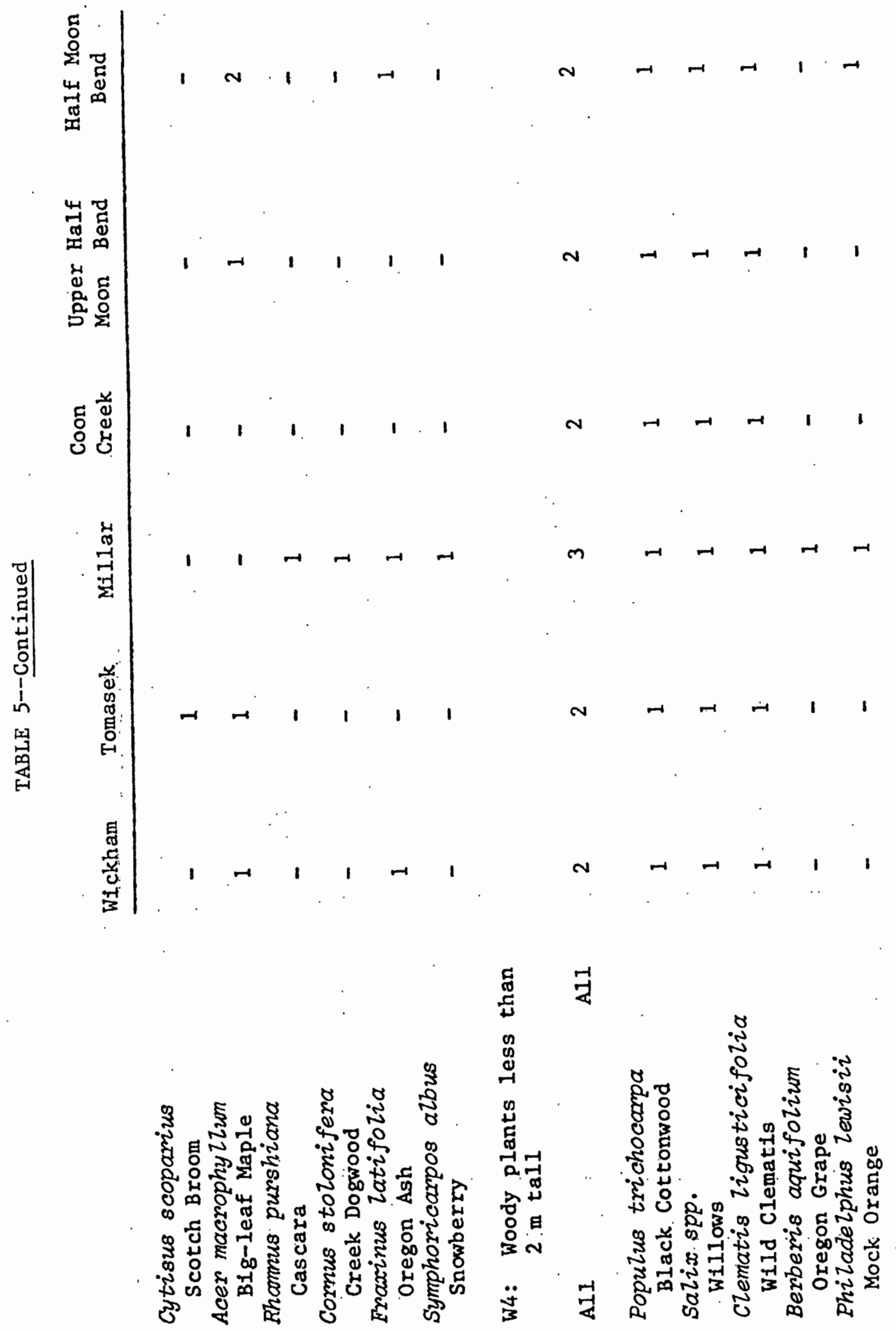




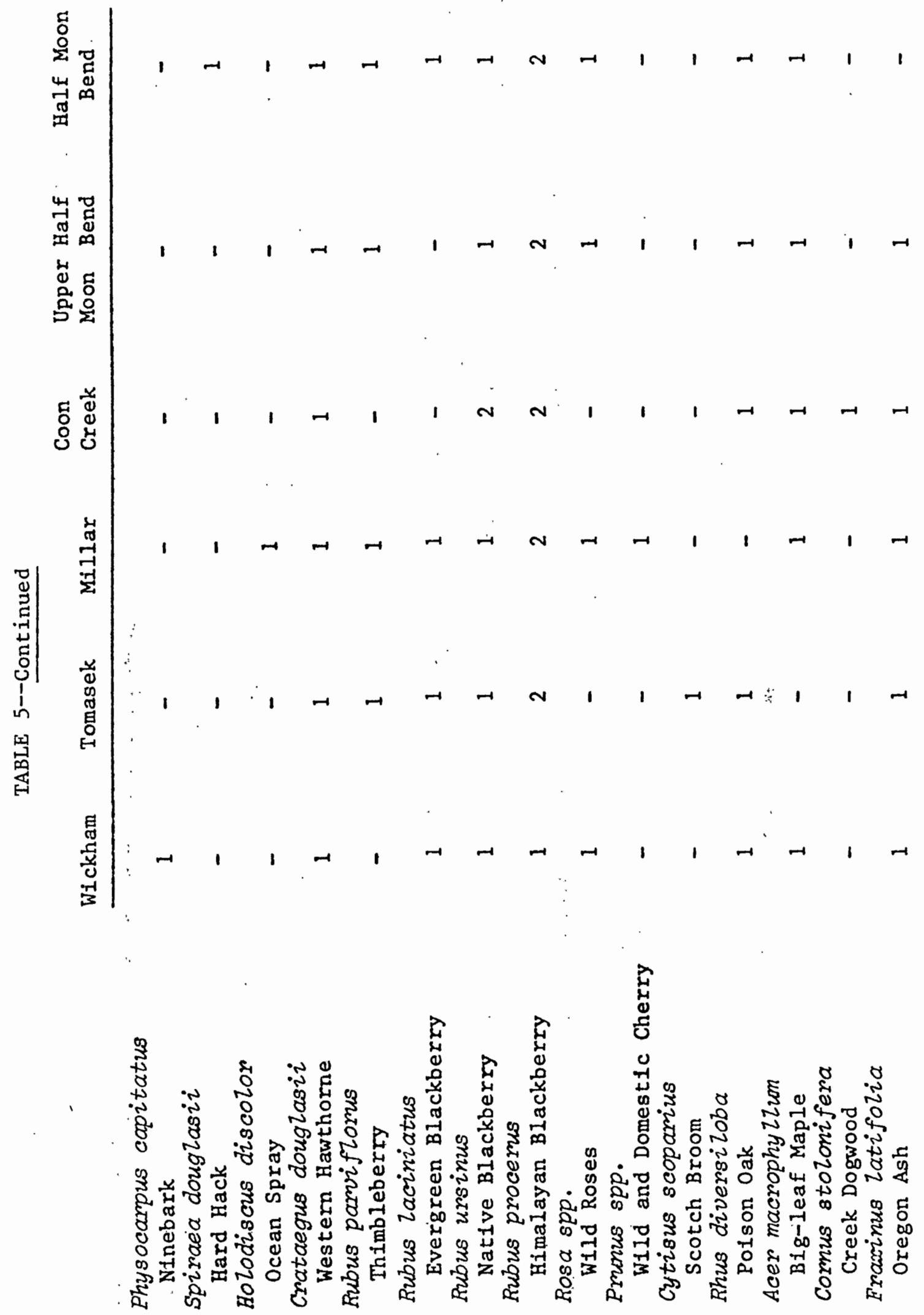




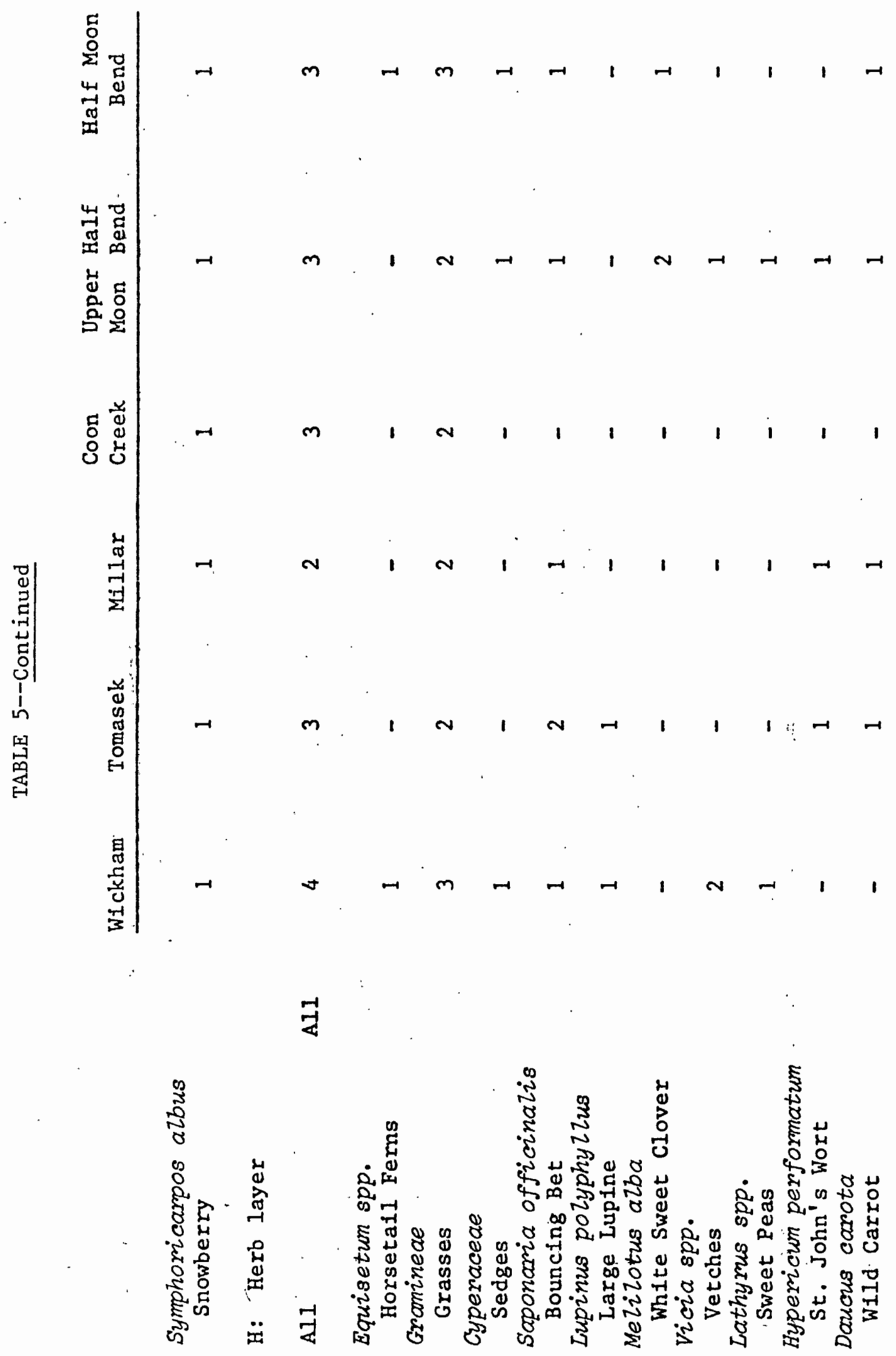




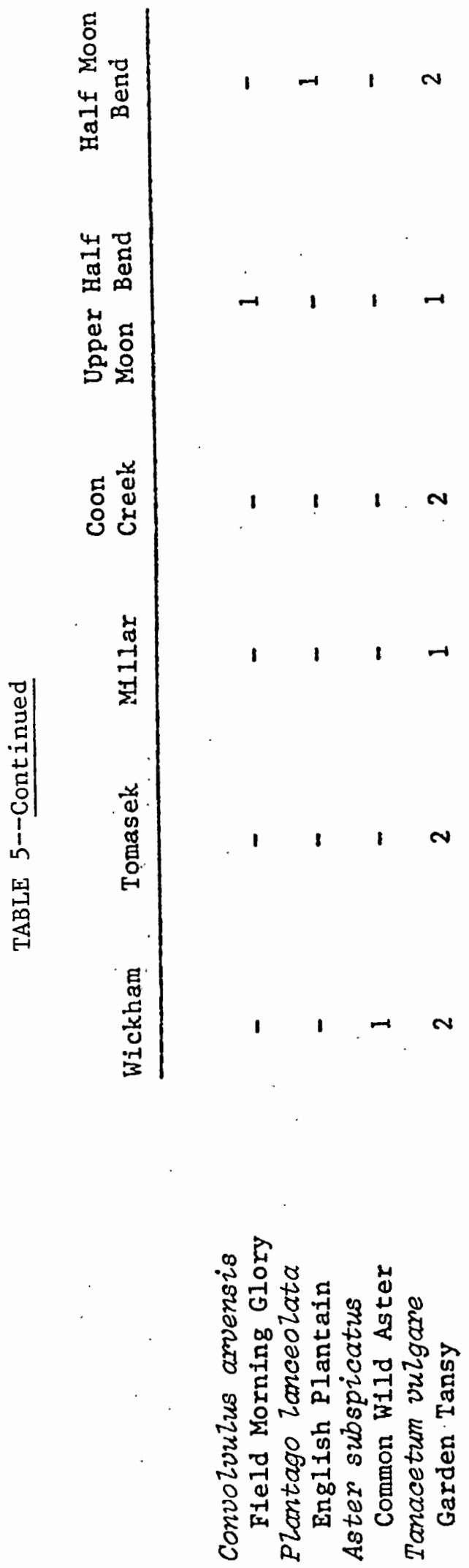

